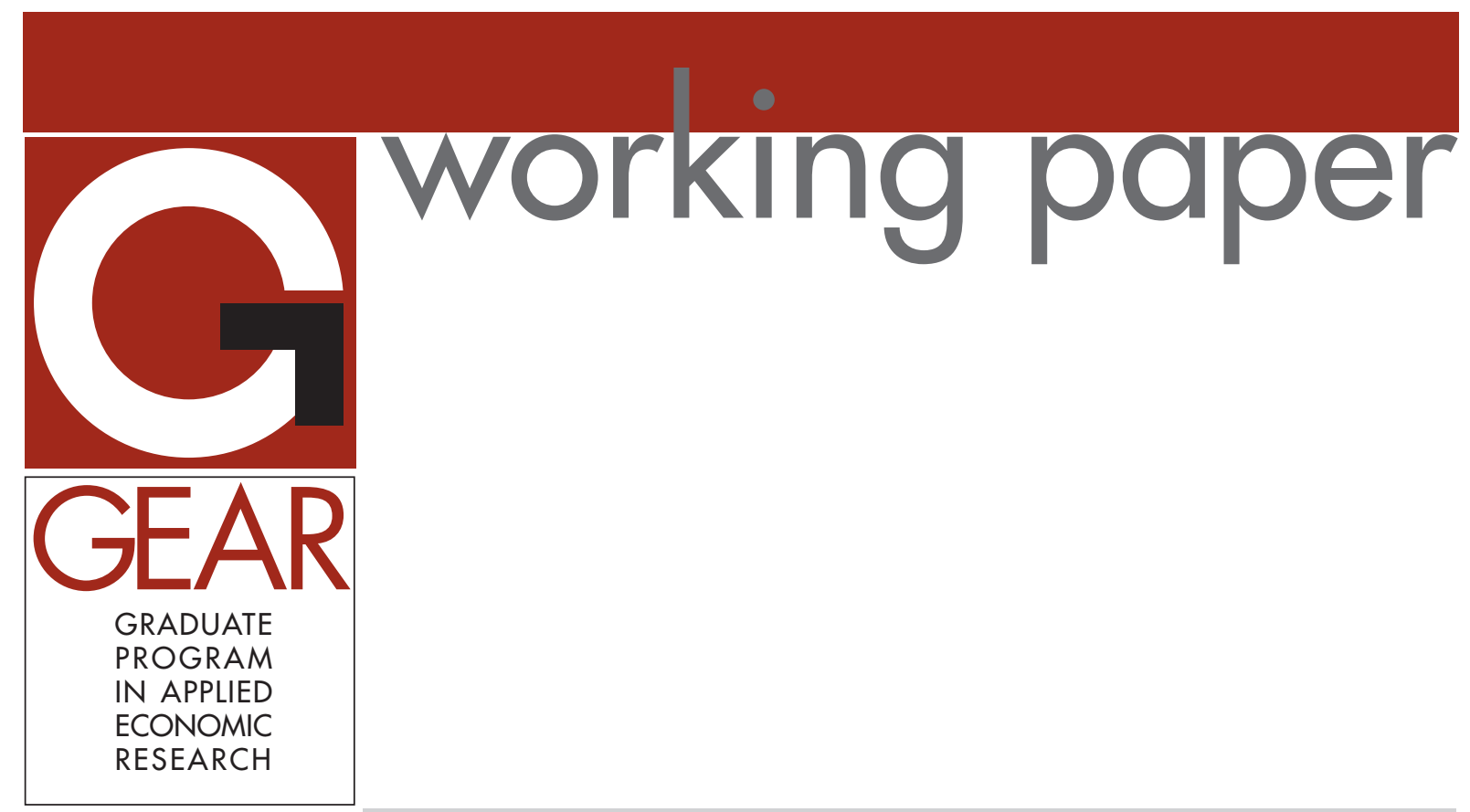

\title{
Non-Standard Monetary Policies and Bank Profitability: The Case of Spain
}

\author{
David Tercero-Lucas
}

Working paper:

2020-04 
This collection belongs to:

Departament

d'Economia Aplicada

\section{UAB}

Avinguda de l'Eix Central

Edifici B2

Campus de la UAB

88193 Bellaterra

Bardanyola del Valless

Tel. +34935811680

Fax +34935812292

d.econ.aplicada@uab.cat

www.uab.cat/departament/

economia-aplicada/

Coordinator: Rosella Nicolini (rosella.nicolini@uab.cat)

This collection is licensed under a Creative Commons Attribution-NonCommercial NoDerivatives 4.0 International License.

\section{(c) (i) (9)}

This collection includes a selection of research by students of the PhD Program in Applied Economics (UAB) and the Master of Applied Research in Economics and Business (MAREB) specialization in Applied Economics. Research contributions can be published in English or Spanish. 


\title{
Non-Standard Monetary Policies and Bank Profitability: The Case of Spain*
}

\author{
David Tercero-Lucas ${ }^{\dagger}$ \\ Universitat Autònoma de Barcelona
}

September 6, 2020

\begin{abstract}
The aim of this study is to examine the effects of non-standard monetary policy measures implemented by the Eurosystem on the Spanish banking sector profitability. To do this, a new database is built merging data from the Spanish Banking Industry Statistical Yearbook and from the Spanish Stock Market Commission. Applying different econometric techniques to a panel of 54 Spanish banks that covers the period 2001-2017 and controlling for bank-specific factors and macroeconomic conditions, no discernible impact is found between the Eurosystem's non-standard monetary policy measures (ECB's total assets, excess reserves and the slope of the yield curve) and bank profitability measured as return on assets, pre-tax operating income and interest margins. This result is robust to different specifications and to different groups of banks.
\end{abstract}

JEL Classification: E52 E58 G21

Keywords: Non-standard Monetary Policy Measures, Banking Sector, Profitability

*The research leading to these results has received the support of a fellowship from "la Caixa" Foundation (ID 100010434). The fellowship code is LCF/BQ/ES18/11670005".

${ }^{\dagger}$ Personal email: davidterluc94@hotmail.com 


\section{Introduction}

This paper evaluates whether the non-standard monetary policy measures implemented by the Eurosystem have had any effect on the profitability of the Spanish banking sector. Non-standard monetary policy measures commenced in the first half of 2008 as a response to the financial turmoil of the Great Recession. Their first aim was to satisfy the urgent liquidity needs of depository institutions. ${ }^{1}$ In 2009 and 2010, the ECB introduced new unconventional measures which were complementary to interest-rate decisions: one-year long-term refinancing operations (LTROs); a covered bonds purchase program; and the first sovereign bond purchase program, the Securities Markets Program (SMP) (Szczerbowicz, 2015). The sovereign debt crisis forced the ECB to activate its SMP again and put in place a second covered bond purchase program. Once there was no more room to cut interest rates, the European monetary authority deployed a package of measures from 2014 onwards, including credit easing measures, a third covered bond purchase program, an asset-backed securities purchase program, a corporate sector purchase program, and new targeted longer-term refinancing operations. Although Eurozone economies started to grow, inflation did not reach the 2 percent target, so the asset purchase program was prolonged several times until the end of 2018 (Hartmann and Smets, 2018). These non-standard monetary policy measures deployed by the ECB resulted in an unprecedented expansion of its balance sheet (see Figure 1).

Figure 1: Eurosystem total assets (€million)

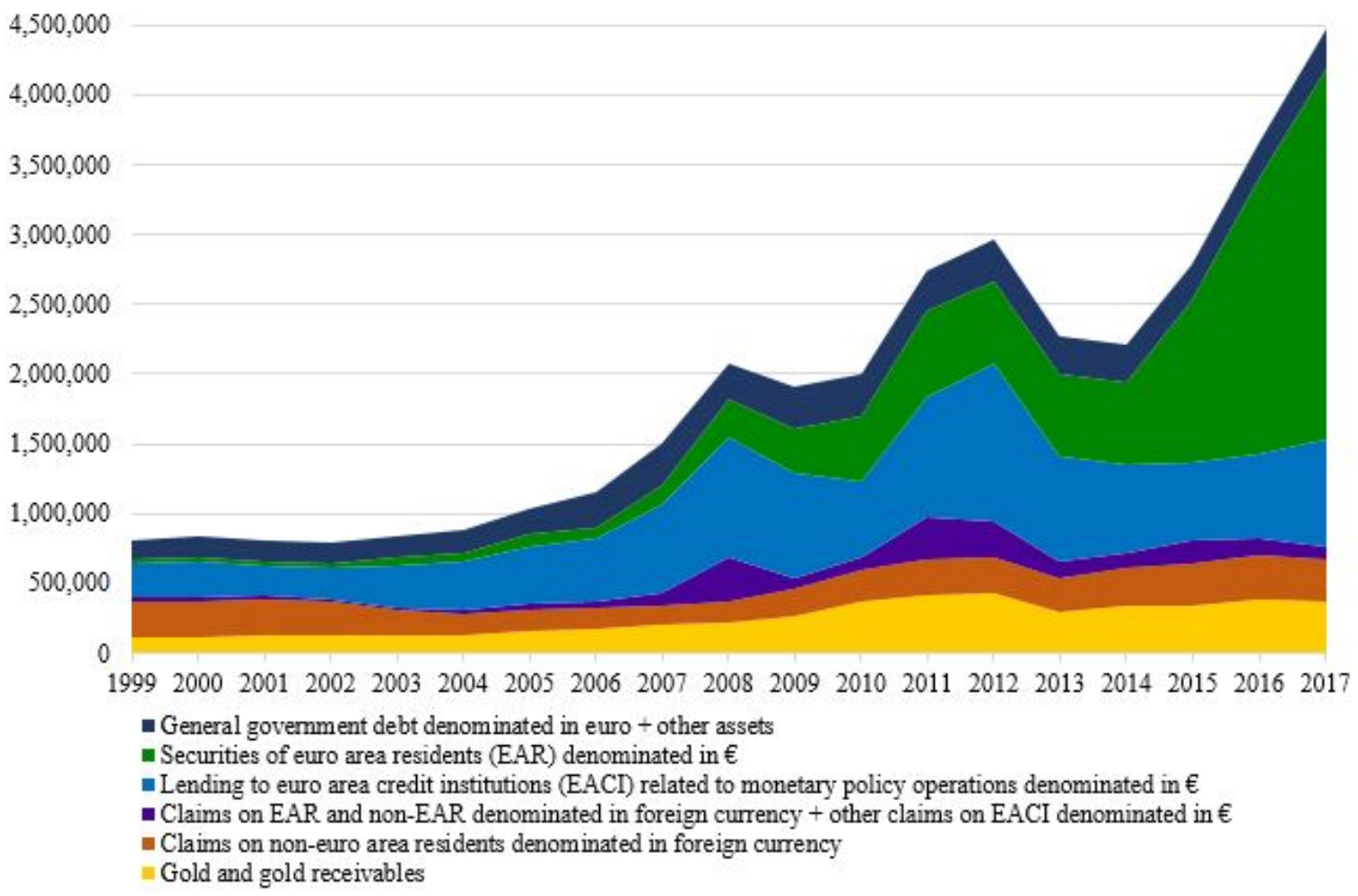

Source: ECB

\footnotetext{
${ }^{1}$ There are several types of non-standard monetary policies: quantitative easing programs, negative interest rates, long-term refinancing operations and forward guidance.
} 
Given the scale of the measures, a plethora of studies have tried to identify their effects in the Eurozone on output and inflation (Gambacorta et al., 2014; Peersman, 2011), interest rates (Ambler and Rumler, 2019), bond yields (Abidi and Miquel-Flores, 2018; Blot et al., 2019; Scotti et al., 2014), stock prices and exchange rates (Haitsma et al., 2016; Scotti et al., 2014), financial stability (Heider et al., 2018), wealth distribution of households (De Luigi et al., 2019) and on small and medium-sized enterprises (Ferrando et al., 2019) among others. ${ }^{2}$

Non-standard monetary policies may also have affected the banking sector via three main channels: the portfolio channel, the liquidity channel, and the signalling channel (Bowdler and Radia, 2012). Their effects, however, remain unclear. On the one hand, quantitative easing depresses long-term interest rates and flattens the yield curve, which may reduce bank earnings on maturity transformation activities (negative effect). It also hurts bank profitability when deposit rates are close to the zero-lower bound, since financial institutions are reluctant to pass negative rates through to commercial deposits (negative effect). On the other hand, quantitative easing measures may generate capital gains because of the increased valuation of bonds in bank portfolios and may lower the cost of debt (positive effect). In addition, non-standard monetary policies may improve the macroeconomic outlook, which may boost the demand for credit and reduce non-performing loans and loan loss provisioning (positive effect). Results may depend on the country analysed and the time-period chosen. In the USA, the findings of Montecino and Epstein (2014) suggest that depository institutions that sold Mortgage-Backed Securities (MBS) to the Federal Reserve increased their profits during the 2008-2009 period. Chodorow-Reich (2014) estimates that the introduction of non-standard monetary policies in the US in 2008 had a positive impact on financial institutions, with even bigger effects on life insurance companies. Lambert and Ueda (2014) found that bank profitability and risk-taking in the US banking sector are ambiguously affected by non-standard monetary policies. In a similar vein, Lopez et al. (2018) investigated the effect of negative nominal interest rates on bank profitability using a panel of 5,100 European and Japanese banks, determining that negative nominal interest rates have a small effect on bank profitability. On the contrary, Mamatzakis and Bermpei (2016) estimated that the Federal Reserve's unconventional monetary policies had a negative effect on US bank performance. In the Euro area, Acharya et al. (2019) highlight that the 2012 ECB Outright Monetary Transactions (OMT) program could indirectly recapitalize the European banking sector by influencing the prices of assets held in bank portfolios. In particular, those depository institutions with a significant quantity of bonds issued by Mediterranean European countries benefited the most. Altavilla et al. (2018) studied the impact of both conventional and unconventional Eurozone monetary policies on a sample of more than 50 banks, including eight Spanish banks. They did not find any association between easing of monetary policy and lower bank profits. The main difference between their research and mine is that their data is only from 8 Spanish banks, hence the effects of the ECB's non-standard monetary policies on the profitability of the whole Spanish banking sector are still unknown.

\footnotetext{
${ }^{2}$ See Dell'Ariccia et al. (2018) for a very-detailed summary of the effects of unconventional monetary policies in the Euro Area, Japan, and the United Kingdom. See Kuttner (2018) for a similar analysis in the United States.
} 
Amongst the different types of bank business models, the traditional financial intermediation model predominates in Spain. Loans to the non-financial private sector and deposits taken by the private sector account for a much higher percentage of Spanish banks' total assets than in other European countries (Maudos and Vives, 2016), so a significant number of households and companies meet their finance needs via direct bank intermediation. The banking sector has always been particularly important to the Spanish economy. In fact, the Spanish banking sector, and the rest of the Eurozone banking system, are cornerstones of the Eurozone's monetary policy. Nowadays, financial institutions complain about the negative effects that some non-standard monetary policies have on their profits. A sound banking sector is crucial for a country like Spain. Spanish banks retain a critical role in direct intermediation and can also be considered managers of financial risk. Effective financial intermediation and sound financial institutions are clearly linked to a sound economy (Camdessus, 1997). The impact of a financial system breakdown would be huge and the associated fiscal costs of bailouts should be considered.

Non-standard monetary policies deployed by the Eurosystem could affect bank profitability and hence financial stability and soundness (Altavilla et al., 2018). Besides, the ability of banks to provide credit to other economic agents could be hindered (Freixas et al., 2015). Therefore, this study tackles an issue hotly debated in the media, trying to shed light on this relationship and offer new insights into the fourth-largest economy of the Eurozone. This paper is a case study which contributes to the literature about the impact of monetary policy actions on bank performance. Understanding the effects of non-standard measures, especially their potential negative impacts, has significant policy implications

The financial crisis hit Spanish commercial and saving banks directly and hard enough that there were not only some bailouts, but also a massive restructuring of the banking sector. On the one hand, some savings banks merged to create new entities (e.g. Bankia, Abanca, Liberbank, or Unicaja). The rest, on the other hand, were absorbed by the main Spanish commercial banks. This fact should be controlled for in my investigation, so this paper differs from the rest of the literature by taking non-consolidated data from 54 commercial banks into account and constructing new 'virtual entities' which capture the Spanish banking sector transformation process and the impact of ECB actions on bank profitability.

Applying different econometric techniques and controlling for bank-specific factors and macroeconomic conditions, no discernible impact is found from the ECB's non-standard monetary policy measures, as proxied by ECB total assets, excess reserves, and the slope of the yield curve, on bank profitability, measured as return on assets (ROA) and pre-tax operating income (PTOIR), over the 2001-2017 period. This result is robust to different specifications and robustness checks. In addition, it may be reasonable because of the effects of non-standard monetary policies on the different components of bank profits. Further analysis shows that the previously not discernible association between non-standard monetary policies and bank profitability does not vary depending on different bank sizes, ratios of loans to total assets, or short-term funding. 
The rest of the paper is structured as follows. Section 2 presents an overview of the Spanish banking sector and how non-standard monetary policies could affect bank profitability. Section 3 introduces the data set and variables employed in the analysis. Section 4 discusses the methodology presenting the econometric framework whilst section 5 presents the empirical results. Section 6 stresses the main findings.

\section{The banking sector and non-standard monetary policies}

\subsection{The Spanish banking sector: Some facts}

Amongst all kinds of bank business models in developed countries, in Spain the traditional financial intermediation model predominates. This is reflected in the percentage of Spanish banks' total assets made up by loans to the non-financial private sector and deposits taken by the private sector, which is more than 10 percent higher than the European average (Maudos and Vives, 2016).Therefore, because an important number of households and firms meet their finance needs through direct bank intermediation, the Spanish banking sector and the whole Eurozone banking system are cornerstones of Eurosystem monetary policy. Before the Great Recession and the sovereign debt crisis, the Spanish banking sector had remarkable weaknesses. Maudos (2012) highlights that the creation of the European Monetary Union led to a low nominal interest rate environment, with negative real interest rates in some countries, which Spanish commercial and saving banks took advantage of. This excessive liquidity was canalized through a significant increase in loans, not only from commercial banks, but especially from savings banks. As Figure 2 shows, the ratio of private sector loans to GDP rose from 89 percent in 2001 to 168 percent in 2008, which implies that loans growth was higher than GDP growth. On the other hand, loans grew more than deposits in the first half of the decade. Since 2008, however, they have decreased to a greater extent than deposits. The loans-to-deposits ratio fell from its peak in 2007 of 168 percent to 110 percent in 2017.

Before the real estate bubble burst, Spanish bank profitability, measured as return on assets (ROA) or profits before tax to total assets, had always been, on average, higher than the ROA of other European countries such as France, Germany, and Italy (with a few exceptions). Figure 3 shows the quite important fact that, since the recovery of the Spanish economy, bank profitability has never returned to pre-crisis levels (0.8-1.1 percent). Since 2013, the ROA has oscillated between 0.0 percent and 0.4 percent. Figure 4 shows that the interest margin of the Spanish banking sector has followed a trend similar to ROA and has not returned to its previous level. The financial crisis eroded bank interest margins and they have not recovered since. Besides, the low nominal interest rate environment before 2007 caused households and non-financial companies to start using leveraging. However, after 2007 some of them started defaulting on their loans. On the contrary, the leveraging ratio of the banking sector remained almost constant from 2001 to 2012, but it has increased from then on. 
Figure 2: Loan and deposit indicators (in percentage)

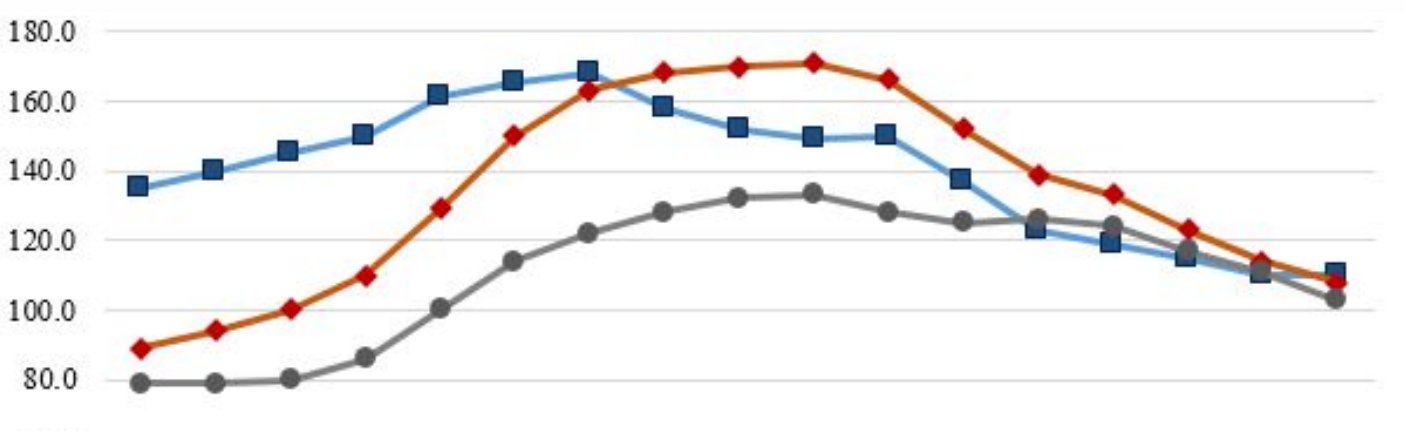

60.0

40.0

20.0

0.0

20012002200320042005200620072008200920102011201220132014201520162017

Loans-to-Deposits $\multimap$ Lending to the private sector / GDP $\rightarrow$ Private sector deposits / GDP

Source: BBVA Research

Although the financial crisis affected both commercial and saving banks, the latter almost disappeared. Their reckless behavior, partly explained by the presence of public authorities on their boards of directors, led to excessive risk-taking (García-Marco and Robles-Fernández, 2008). Those which did not go into bankruptcy formed new entities or were absorbed by larger commercial banks. The financial crisis provoked a tremendous consolidation of the Spanish banking sector and the creation of new "super-banks". ${ }^{3}$

\subsection{Bank profitability and monetary policy in the literature}

The relationship between bank profitability and conventional monetary policy has been studied since the 1940s. Samuelson (1945) emphasized that an increase in the interest rate boosts bank profitability via an increase in bank interest margins. An interest rate increase will push up the interest rates of loans to a greater extent than the interest rates paid on bank deposits. The study of Hancock (1985) supports this hypothesis. He estimated that the profit elasticity of loans is larger than the profit elasticity of term deposits. On the contrary, Flannery (1981) found no clear relationship between market interest rate levels and bank profitability, and showed that large banks hedged against interest rate risks. Apart from the impact of monetary policy on interest margins, interest rate changes may also affect the term premium, altering the yield curve and thus bank profitability (English, 2002; English et al., 2012). The study by Borio et al. (2017) confirms that the interest rate level has a positive and significant relationship with both bank profitability and the slope of the yield curve. In a similar line, Demirgüç-Kunt and Huizinga (1999) found that an increase in interest rate levels increases interest margins and profitability.

\footnotetext{
${ }^{3}$ For instance, the sum of the assets of Banco Santander, BBVA, Banco Sabadell and Bankinter in 2007 accounted for 28.7 percent of Spanish banks' total assets, whereas in 2017 they accounted for 43.0 percent.
} 
Figure 3: ROA by country (in percentage)

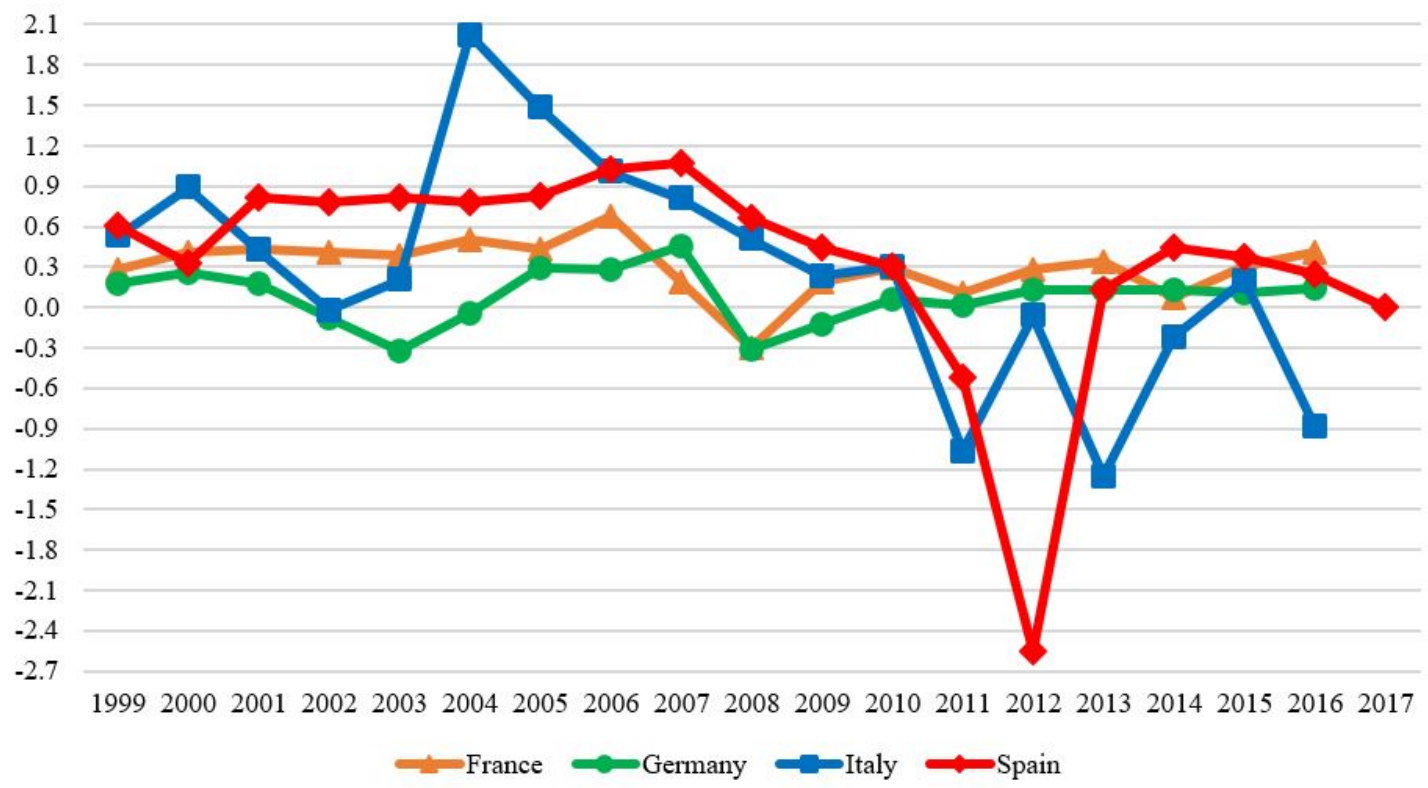

Source: BBVA Research and ECB

However, Lopez et al. (2018) show that, compared to low positive rates, negative nominal interest rates have only a small effect on bank profitability.

On the other hand, the literature has established three different main channels through which non-standard monetary policies - i.e. purchase of government bonds from investors like banks or pension funds - may have an impact on the profitability of the banking sector, especially via their effect on asset prices (Bowdler and Radia, 2012). The first is the so-called "portfolio rebalancing" channel. Tobin $(1963,1969)$ and Brunner and Meltzer (1972) highlight that central bank asset purchases provide cash to the owners of the assets. Since cash and the assets bought are not perfect substitutes for each other, financial institutions will use that cash to buy closer substitutes for previous assets, rebalancing their portfolios and taking more risks than if they had just held the money. The second channel is the "liquidity channel". Quantitative easing reduces the net supply of longer-term assets which provokes an increase in their prices and a decrease in their yields (Altavilla et al., 2018). The provision of liquidity through asset purchase programs to not only the financial sector, but also the non-financial sector, reduces the liquidity premia associated with times of financial distress (Bowdler and Radia, 2012). Non-standard monetary policies can also affect the banking sector via the "signalling channel". The Global Financial Crisis made forward guidance an essential tool of central bankers (McKay et al., 2016). When the ECB reveals its possible future policy decisions, it signals economic prospects to the market. Maintaining the asset-purchase programs for a long period of time may signal that because the economic situation is still fragile (Mamatzakis and Bermpei, 2016), there is an intention to keep short-term interest rates low for a long period of time (Altavilla et al., 2018) and that long-term interest rates may decrease (Bowdler and Radia, 2012). This mechanism is closely related to the interest rate channel proposed by Samuelson (1945). 
Figure 4: Some bank indicators (in percentage)

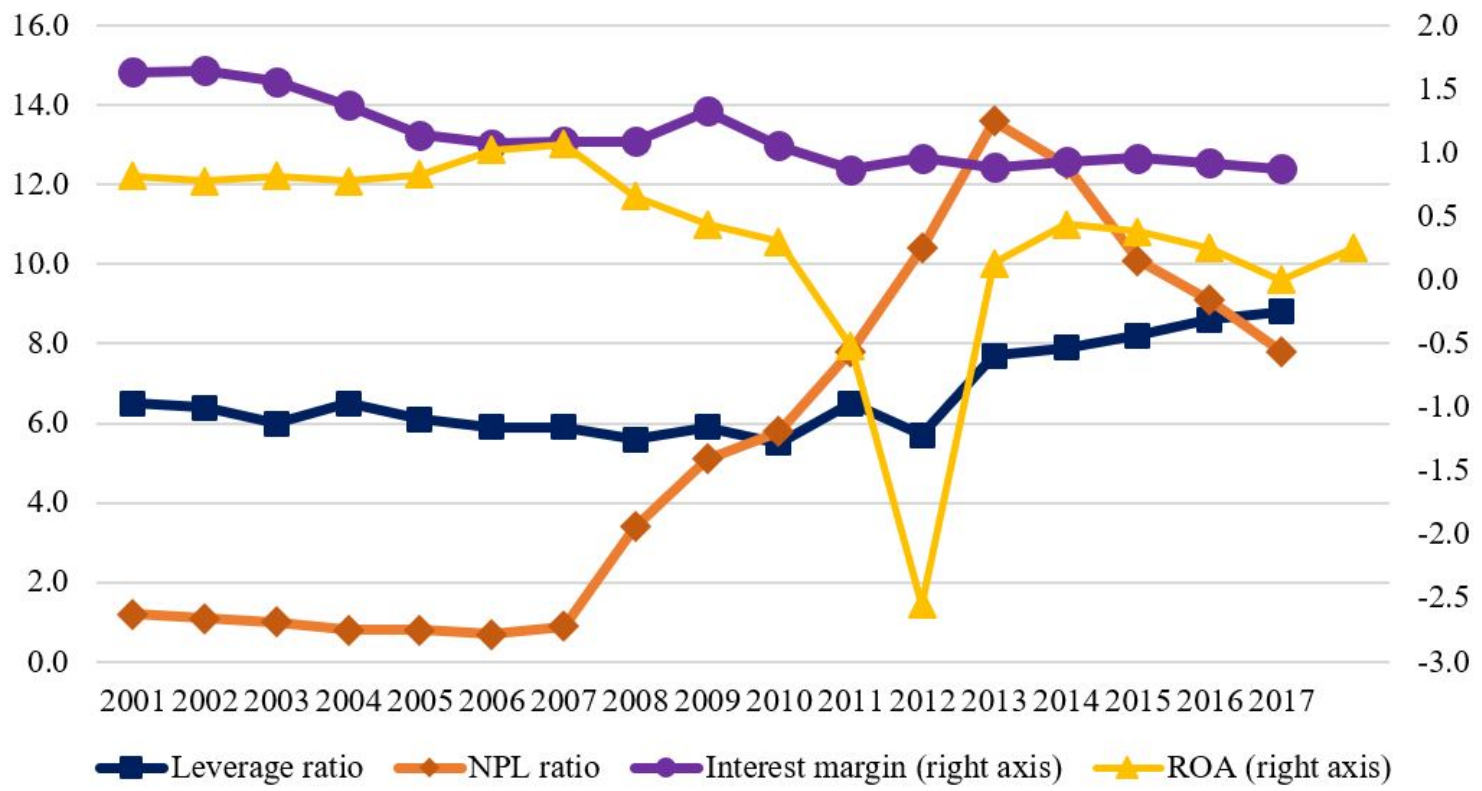

Source: BBVA Research

Empirical studies trying to disentangle the different effects of non-standard monetary policy on the profitability of the banking sector started with Lambert and Ueda (2014) and Montecino and Epstein (2014). The first study showed that bank profitability and risk-taking in the US banking sector are not really affected by the Fed's unconventional monetary policies (Lambert and Ueda, 2014). The second one showed that depository institutions that sold MBS to the Federal Reserve increased their profitability during the 2008-2009 period (Montecino and Epstein, 2014). Mamatzakis and Bermpei (2016) estimated that the Federal Reserve's unconventional monetary policies had a negative effect on US bank performance. In the Eurozone, once Altavilla et al. (2018) did not find any association between monetary policy easing and lower bank profits once they controlled for the endogeneity of the policy.

\section{Data and variables}

I constructed a new database employing annual data from the Spanish Banking Industry Statistical Yearbook of the Spanish Banking Association for the period from 1999 to $2017 .^{4}$ However, the yearbook does not include all those new entities created after 2010, most of which were created by mergers of troubled savings banks. To ensure I included them in the sample, data from the Spanish Stock Market Commission was employed (CNMV).

Some Spanish depository institutions are major global firms which are thus exposed to different markets, not only inside the European Union but also in Latin America and Asia. Since I am only interested in the effects of the ECB's non-standard monetary policies on the outcomes of Spanish banks, non-consolidated data is used.

\footnotetext{
${ }^{4}$ In the empirical models, data from 2001 to 2017 will be employed because there is no data prior to 2001 for some country-level variables.
} 
Consolidated data could distort my results because the balance sheets of headquarters and subsidiaries may cancel each other out. The Spanish Banking Association reports both non-consolidated (in Spain only) and consolidated data. The sample is adjusted following Borio et al. (2017).I controlled for 47 mergers and acquisitions over the 1999-2017 period by constructing "new virtual entities" which are derived from adding balance sheets (see Table A1 and A2 in the Appendix). This is key in the Spanish context because there has been tremendous consolidation in the banking sector since the beginning of the Great Recession. I am, however, conscious that this method reduces the number of banks in the sample. ${ }^{5}$

The frequency is annual and all variables are in thousand euros. The final sample includes 54 commercial banks ${ }^{6}$ and a total of 742 observations. Inconsistencies and extreme values (outliers) have also been removed. The number of banks varies year to year from a minimum of 35 to a maximum of 54 (with all new created entities included).

\subsection{Dependent variables}

The data provided by the Spanish Banking Association and the Spanish Stock Market Commission allows us to compute different bank profitability measures. The first one is the return on assets (ROA), which is the simplest measure of bank performance. It reflects the ability of a depository institution to obtain profits from its asset management tasks. It is computed as the ratio of total bank profits before taxes over total assets (Mamatzakis and Bermpei, 2016; Pasiouras and Kosmidou, 2007; Trujillo-Ponce, 2013). Profits before taxes are employed to avoid tax system changes. Figure 5 shows the evolution of the return on assets of some of the major Spanish banks. Banco Popular suffered an important crisis in 2016 and 2017 that led to its absorption in 2018 by Banco Santander.

The return on equity (ROE) is also another measure of profitability widely used. Nevertheless, neither the Spanish Banking Association nor the Spanish National Stock Market Commission provide me enough information to compute it over the whole period considered. As a complement to ROA, the pre-tax operating income to total assets ratio (PTOIR) will be employed (Mamatzakis and Bermpei, 2016). Additionally, another measure used in the literature is the interest margin because it is a momentous source of bank profitability (Mamatzakis and Bermpei, 2016).

\footnotetext{
${ }^{5}$ I have had to keep track of all changes in banks names during the 1999-2017 period. Table A3 in the Appendix provides a follow-up on this matter.

${ }^{6}$ Banks in the sample are: A\&G Banca Privada, Allfunds Bank, AndBank España, Aresbank, BNP Paribas España, Banca Pueyo, Banco Alcalá, Banco Europeo de Finanzas, Banco Finantia Sofinloc, Banco Inversis, Banco Mediolanum, Banco Pichincha España, Banco de Depósitos, Banco de la Nacion Argentina, Bancofar, Bank Degroof Petercam Spain, Bankoa, Banque Marocaine du commerce exterieur international, Citibank España, Credit Suisse Ag, EBN Banco de Negocios, JP Morgan Chase Bank National Association, Nuevo Micro Bank, Popular Banca Privada, Renta 4 Banco, Self Trade Bank, The Bank of Tokyo Mitsubushi UFJ, UBS Bank, Abanca, BBVA, Banca March, Banco Caixa Geral, Banco Caminos, Banco Cooperativo Español, Banco Pastor, Banco Popular Español, Banco Santander, Banco de Crédito Social Cooperativo, Banco de Sabadell, Bankia, Bankinter, Caixabank, Deutsche Bank, EVO Banco, Ibercaja, Kutxabank, Liberbank, Open Bank, Santander Consumer Finance, Santander Investment, Santander Securities Services, Targobank, Unicaja and Wizink Bank.
} 
Figure 5: ROA of some of the main Spanish banks (Banco Popular right axis)

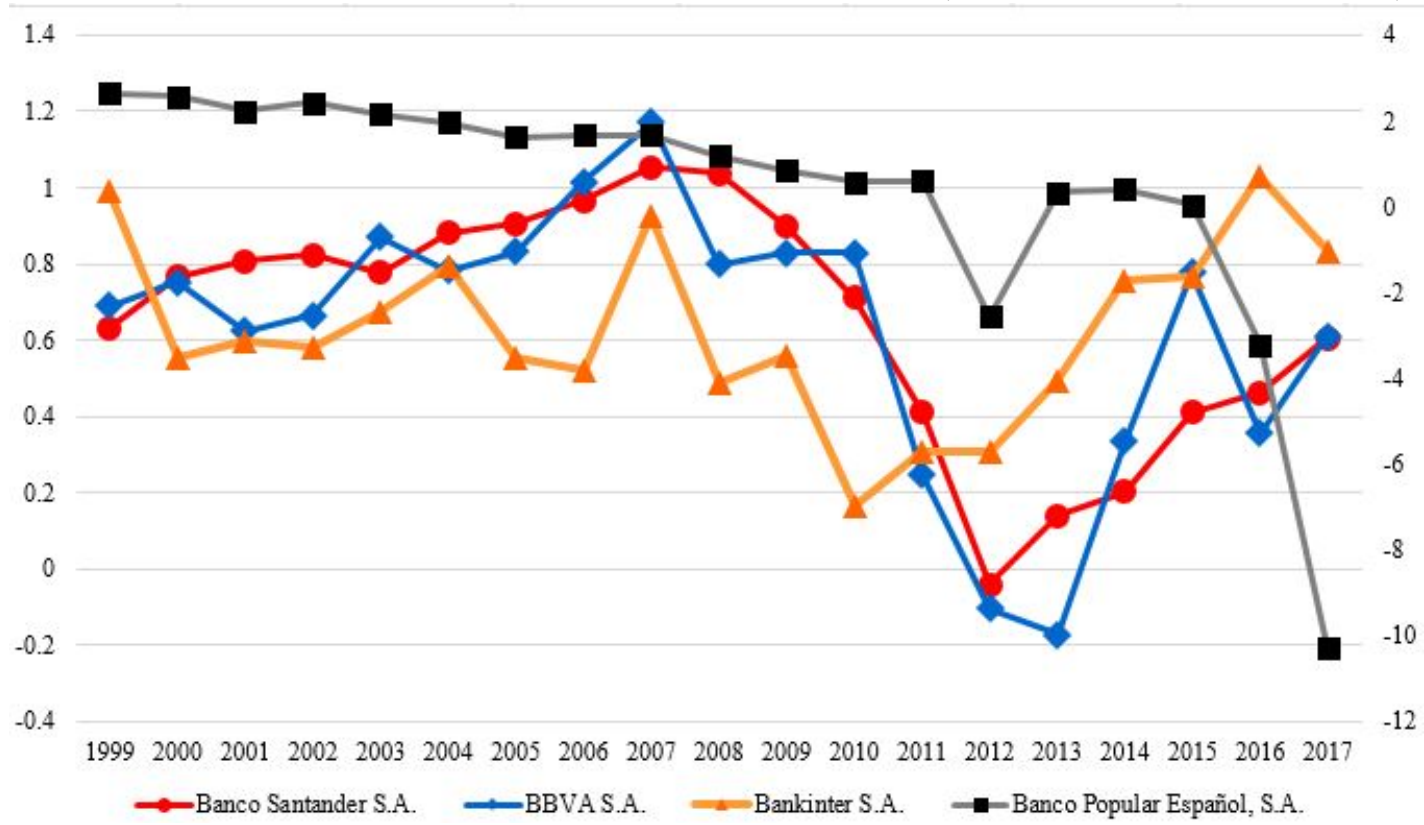

Source: Spanish Banking Association and Spanish Stock Market Commission

The interest margin is the difference between the interest rate of lending and the interest rate of deposits. García-Herrero et al. (2009) highlight that the interest margin is an appropriate measure of profitability if the behavior of banks is the one which determines interest rate revenues and expenses and not government policies. Although in the literature the net interest margin is computed as a percentage of the average earning assets, I will employ the interest margin to total assets ratio (IMR) because of data availability.

\subsection{Non-standard monetary policy variables}

Since the outbreak of the Great Recession, the ECB has notably expanded the size of its balance sheet both in the asset and liability side. In the first place, by providing liquidity to depository institutions. Secondly, by starting asset purchase programs and holding Eurozone securities. The increase in the asset side of the ECB's balance sheet can be appreciated in Figure 6. In 2008 the ECB's total assets were $€ 2.075$ trillion whereas in 2018, they are $€ 4.702$ trillion. Several studies have employed the asset side of the central bank as a measure of non-standard monetary policies to assess its effects on some macroeconomics variables. For instance, Gambacorta et al. (2014) demonstrate that an exogenous increase in the central bank balance sheet increases temporarily output and inflation and Eser and Schwaab (2013) study the impact of the ECB's Securities Markets Programme (2010-2011) on sovereign bond markets. Using also this measure, Chodorow-Reich (2014) proves that the introduction of unconventional monetary policies by the US Federal Reserve benefited banks. However, Lambert and Ueda (2014) find that, in the US, bank profitability and risk taking are vaguely affected by them. On the contrary, Mamatzakis and Bermpei (2016) show that the increase in the asset side of Fed's balance sheet has a negative relationship with bank profitability. Hence, I use the logarithm of ECB's assets as a first measure of non-standard monetary policy measures. 
Figure 6: ECB total assets and Euro area banks excess reserves (right axis) (€million)

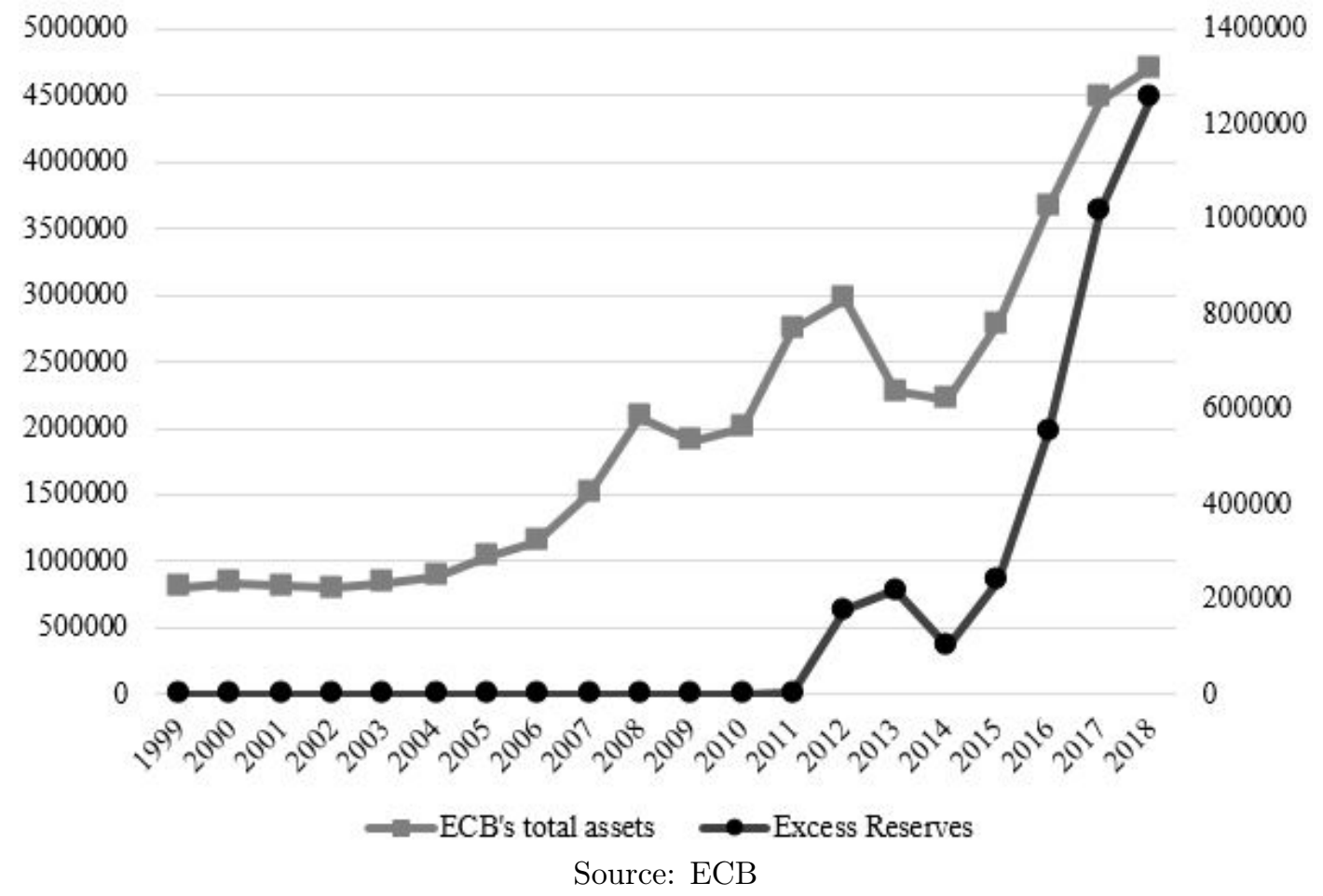

As in the case of the US (Keister and McAndrews, 2009; Todd, 2013), the non-standard monetary policy measures carried out by the ECB have led to a substantial increase in excess reserves held by Eurozone credit institutions (Darvas and Pichler, 2018): from $€ 0.966$ billion in December 2007 to $€ 1.204$ trillion in January 2019 (see Figure 6). Excess reserves are those reserves held by credit institutions at the central bank account in excess of the amount that the ECB requires. Since the mid-2014, the ECB adopted a negative deposit rate on its deposit facility. As Mamatzakis and Bermpei (2016), I employ the logarithm of excess reserves as a second measure of the ECB's non-standard monetary policy measures.

The ECB's total assets and the Eurosystem's excess reserves, are a proxy of asset purchase programs (quantitative easing). They can proxy liquidity injections as well, as the ECB expanded its balance sheet to provide long-term funding to euro area banks. However, these measures are poorly correlated with forward guidance and negative interest rates. This means that they are capturing the "quantity effect" of non-standard monetary policies, but not the "price effect". This "price effect" can be measured by the slope of the yield curve. As in Altavilla et al. (2018), the slope of the Spanish yield curve will be computed as the difference between the 10-year Spanish bond yield and the 2-year Spanish bond yield.

\subsection{Bank and country-level data}

In the literature several variables have been used as controls. I will split these factors that influence banks' performance in two different categories: bank-specific factors and macroeconomic variables which capture the Spanish economic conditions. 


\subsubsection{Bank-specific factors}

A natural variable to control for existing economies of scale is bank total assets (proxied by bank size). The empirical evidence on the relationship between size and profitability depends on the country and period analyzed. Some authors argue that large banks tend to raise less expensive capital than smaller banks so they can be more profitable (Short, 1979). Others argue that large banks gain from being more diversified (Mester, 1993). On the other hand, large banks can also be negatively affected by bureaucracy and other kinds of rigidities (Athanasoglu et al., 2008; Demirgüç-Kunt and Huizinga, 2000). The natural logarithm of banks' total assets is used. Another relevant variable to account for is the customer loans to total assets ratio (García-Herrero et al., 2009; Mamatzakis and Bermpei, 2016). To capture possible liquidity problems (Petria et al., 2015), the loan to customer deposits ratio is used. Trujillo-Ponce (2013) argues that when there is an extreme competition to capture deposits, depository institutions will increase the interest rate they offer losing revenues. Hence, the annual growth rate of customer deposits will be considered.

An additional control variable to be taken into consideration is market power. The structure-conduct-performance hypothesis states that monopolistic profits are derived from higher levels of market power. In the literature, market power is proxied by taking the share of individual total assets to the whole sector total assets (García-Herrero et al., 2009; Petria et al., 2015). I do the same here. ${ }^{7}$

\subsubsection{Macroeconomic conditions}

To capture the Spanish economic conditions I employ a set of macroeconomic variables such as real GDP growth, inflation, stock market volatility and ECB's main refinancing operations (MRO) interest rate. A higher economic growth is related to an increase of the demand for loans by households and firms (Petria et al., 2015), which could be translated to a higher bank profitability. Economic growth is proxied by the real GDP growth (Bikker and Hu, 2002; García-Herrero et al., 2009; Mamatzakis and Bermpei, 2016; Avalos and Mamatzakis, 2018). An increase in the consumer price index may affect not only wages but also other costs of financial institutions (Revell, 1979). Perry (1992) argues that if depository institutions anticipate inflation their revenues will increase to a greater extent than their costs because they will adjust properly interest rates. The opposite would happen if inflation is not unanticipated, with its negative effects on bank profitability. Therefore, the effects of inflation in bank performance are uncertain.

As in Lambert and Ueda (2014), the volatility of stock price index is used to control for the stress in the stock market. Higher stock market volatility can negatively affect bank performance. Finally, the ECB's MRO interest rate is included to control for the conventional monetary policy of the European monetary authority. A positive relationship is expected on bank profitability (Jimenez et al., 2013), especially on the interest margin variable.

\footnotetext{
${ }^{7}$ I would have also liked to control for other bank-level variables such as the liquid assets to total assets ratio or a funding costs variable. Unfortunately, such variables are not included in the Spanish Banking Association files.
} 
Table 1: Summary of variables. Definition and sources

\begin{tabular}{|c|c|c|}
\hline Variable & Definition & Statistical Source \\
\hline \multicolumn{3}{|l|}{ Dependent variables } \\
\hline Return of assets (ROA) & $\begin{array}{l}\text { Individual profits before tax per bank } \\
\text { over total assets per bank }\end{array}$ & $\mathrm{AEB}$ and $\mathrm{CNMV}^{*}$ \\
\hline $\begin{array}{l}\text { Pre-tax operating income } \\
\text { ratio (PTOIR) }\end{array}$ & $\begin{array}{l}\text { Pre-tax operating income over total } \\
\text { assets }\end{array}$ & $\mathrm{AEB}$ and CNMV \\
\hline Interest margin ratio (IMR) & Interest margin to total assets ratio & $\mathrm{AEB}$ and $\mathrm{CNMV}$ \\
\hline \multicolumn{3}{|l|}{ Independent variables } \\
\hline $\begin{array}{l}\text { Eurosystem total assets } \\
\text { (ESTA) }\end{array}$ & $\begin{array}{l}\text { Assets that the Eurosystem national } \\
\text { central banks and the ECB held at } \\
\text { the end of the year with third parties }\end{array}$ & $\mathrm{ECB}$ \\
\hline Excess reserves (EERR) & $\begin{array}{l}\text { Reserves held by credit institutions } \\
\text { at the central bank account in excess } \\
\text { of the amount that the ECB requires }\end{array}$ & ECB \\
\hline $\begin{array}{l}\text { Slope of the yield curve } \\
\text { (SYC) }\end{array}$ & $\begin{array}{l}\text { Difference between the } 10 \text {-year } \\
\text { Spanish bond yield and the } 2 \text {-year } \\
\text { Spanish bond yield }\end{array}$ & Bloomberg \\
\hline Bank size $(\mathrm{BS})$ & Natural logarithm of total assets & $\mathrm{AEB}$ and CNMV \\
\hline Loans to assets ratio (LTA) & Customer loans over total assets & Own calculations \\
\hline Loans to deposits (LD) & $\begin{array}{l}\text { Customer loans over customer } \\
\text { deposits }\end{array}$ & Own calculations \\
\hline Deposits growth (DG) & Customer deposits growth per year & Own calculations \\
\hline Market power (MP) & $\begin{array}{l}\text { Total assets per bank over the total } \\
\text { assets of the whole banking sector }\end{array}$ & $\begin{array}{lr}\text { BBVA } & \text { Research } \\
\text { and } & \text { own } \\
\text { calculations }\end{array}$ \\
\hline Real GDP growth (RGDP) & $\begin{array}{l}\text { Real Gross Domestic Product change } \\
\text { per year }\end{array}$ & Eurostat \\
\hline Inflation (INF) & Change in the price index & Eurostat \\
\hline $\begin{array}{l}\text { Volatility of stock price } \\
\text { index (VSPI) }\end{array}$ & $\begin{array}{l}\text { Natural logarithm of the } 360 \text {-day } \\
\text { standard deviation of the return on } \\
\text { the Spanish stock market index }\end{array}$ & $\begin{array}{l}\text { Fed Bank of St. } \\
\text { Louis }\end{array}$ \\
\hline $\begin{array}{ll}\text { Main refinancing } \\
\text { operations rate }(\mathrm{MRO})\end{array}$ & $\begin{array}{l}\text { Interest rate depository institutions } \\
\text { pay when they borrow money from } \\
\text { the ECB for one week }\end{array}$ & $\mathrm{ECB}$ \\
\hline
\end{tabular}

$\overline{\text { Source: Author's elaboration. *AEB stands for Spanish Banking Association. CNMV stands for }}$ Spanish Stock Market Commission.

\subsection{Descriptive statistics}

Table 2 presents a summary of the descriptive statistics of all variables employed in the analysis. ${ }^{8}$ On average, bank profitability measured as ROA is 0.57 , as pre-tax operating income it is 0.74 and as interest rate margin it is 1.68. The large standard deviations of the loans to deposits ratio and customer deposits growth are due to the important changes in these magnitudes from some small banks from one period to another.

\footnotetext{
${ }^{8}$ The correlation matrix is presented in Table A4 in the appendix.
} 
Table 2: Descriptive statistics

\begin{tabular}{lllll}
\hline \hline Variable & Mean & Std. Dev. & Min & Max \\
\hline Depedent variables & & & & \\
ROA & 0.57 & 2.50 & -32.99 & 16.81 \\
PTOIR & 0.74 & 2.0 & -15.04 & 16.81 \\
IMR & 1.69 & 1.49 & -0.51 & 10.76 \\
Non standard monetary & & & & \\
policy variables & & & & \\
ESTA & 14.44 & 0.54 & 13.58 & 15.31 \\
EERR & 9.23 & 2.89 & 6.50 & 13.83 \\
SYC & 1.57 & 0.67 & 0.19 & 2.62 \\
Bank-level variables & & & & \\
BS & 8.01 & 2.40 & 2.81 & 13.29 \\
LTA & 48.08 & 29.89 & 0.01 & 99.22 \\
LD & 327.15 & 2530.63 & 0.12 & 67339.38 \\
DG & 144.27 & 2221.96 & -99.02 & 52310.39 \\
MP & 1.48 & 3.61 & 0.00 & 18.67 \\
Country-level variables & & & & \\
RGDP & 1.58 & 2.48 & -3.57 & 4.11 \\
INF & 1.99 & 1.52 & -0.50 & 4.08 \\
VSPI & 3.11 & 0.31 & 2.44 & 3.60 \\
MRO & 1.59 & 1.40 & 0 & 4.30 \\
\hline \hline
\end{tabular}

Source: Author's elaboration. The final sample includes 742 observations (the same as in Table 5).

\section{Econometric framework}

The suitable econometric framework to deal with the data I use is a panel data model. Firstly, a static-panel will be considered. In order to identify whether I should employ a fixed-effects model or a random-effects model, the Hausman (1978) test is performed. In the twelve estimated models, the null hypothesis is rejected. This implies that the fixed effect estimator should be used. ${ }^{9}$

The static-panel model that I employ can be summarised by the following expression:

$$
\mathrm{BP}_{\mathrm{i}, \mathrm{t}}=\mathrm{c}+\beta(\mathrm{NSMP})_{\mathrm{i}, \mathrm{t}}+\sum_{\mathrm{j}=1}^{\mathrm{n}} \gamma_{\mathrm{j}}\left(\mathrm{BSF}_{\mathrm{i}, \mathrm{t}}^{\mathrm{j}}\right)+\sum_{\mathrm{k}=1}^{\mathrm{m}} \delta_{\mathrm{k}}\left(\mathrm{MC}_{\mathrm{t}}^{\mathrm{k}}\right)+\mathrm{v}_{\mathrm{i}}+\mathrm{u}_{\mathrm{i}, \mathrm{t}}
$$

In equation 1 subscripts $\mathrm{i}$ and $\mathrm{t}$ index banks and time in years, respectively; $\mathrm{BP}_{\mathrm{i}, \mathrm{t}}$ is the vector of bank-specific measure of the Spanish banks profitability. As stated before, it has been proxied in three different ways: i) the ROA (return of assets), ii) the PTOIR (pre-tax operating income ratio), and iii) the IMR (interest margin ratio). The variable $\mathrm{NSMP}_{\mathrm{i}, \mathrm{t}}$ captures the non-standard monetary policies and is proxied by i) Eurosystem total assets, ii) excess reserves, iii) the slope of the yield curve. The variable $\mathrm{BSP}_{\mathrm{i}, \mathrm{t}}^{\mathrm{j}}$ stands for bank-specific factors as described in Table 1 whilst $\mathrm{MC}_{\mathrm{t}}^{\mathrm{k}}$ stands for macroeconomic conditions, which do not vary across banks. $\beta$, $\gamma_{\mathrm{j}}$ and $\delta_{\mathrm{k}}$ are the rest of the parameters to be estimated. Finally, $\mathrm{v}_{\mathrm{i}}$ is the unobserved bank-specific effect and $u_{i}$ the idiosyncratic error term.

\footnotetext{
${ }^{9}$ See Table A5 and Table A6 in subsection A.3 of the appendix.
} 
Secondly, I should be aware of the potential econometric issues that data could present. The first one is the possible endogeneity character of the explanatory variables. Bank profitability could have an impact on some of the bank-specific variables as well as on macroeconomic determinants. For instance, some measures adopted by the Eurosystem during the crisis have been partially a response to problems in the banking sector. Hence, they may not be truly independent. The second issue is the persistence of bank performance, a well-documented fact in the literature (Knapp et al., 2006). Lastly, unobserved heterogeneity should be taken into account (bank profitability can be affected by some features of depository institutions which are not measurable). The standard methodology to address all my concerns is to apply the generalised method of moments (GMM) dynamic panel estimator, developed for dynamic panel data models by Arellano and Bond (1991) and improved by Arellano and Bover (1995) and Blundell and Bond (1998) which yields consistent and unbiased estimates. ${ }^{10}$ Specifically, I apply a two-step GMM system. This method combines the difference equation with a level equation so as to form a system of equations. $^{11}$

The validity of the GMM system estimator approach relies on two different and important assumptions: i) the instruments will be valid only if they are uncorrelated with the error term, and ii) the GMM system estimator requires that the error terms I have estimated are stationary. The first assumption will be tested through the Hansen J-Statistics of over-identifying restrictions. In addition, the difference-in-Hansen test will be performed. It considers whether the difference between the corresponding Hansen statistics is small enough for the null hypothesis not to be rejected. The second assumption implies the absence of second-order serial correlation in the first difference residual. To test this assumption, I use an statistic developed by Arellano and Bond (1991).

The dynamic panel model that I employ can be summarised in the following expression:

$$
\mathrm{BP}_{\mathrm{i}, \mathrm{t}}=\mathrm{c}+\alpha\left(\mathrm{BP}_{\mathrm{i}, \mathrm{t}-1}\right)+\beta(\mathrm{NSMP})_{\mathrm{i}, \mathrm{t}}+\sum_{\mathrm{j}=1}^{\mathrm{n}} \gamma_{\mathrm{j}}\left(\mathrm{BSF}_{\mathrm{i}, \mathrm{t}}^{\mathrm{j}}\right)+\sum_{\mathrm{k}=1}^{\mathrm{m}} \delta_{\mathrm{k}}\left(\mathrm{MC}_{\mathrm{t}}^{\mathrm{k}}\right)+\mathrm{v}_{\mathrm{i}}+\mathrm{u}_{\mathrm{i}, \mathrm{t}}
$$

In equation 2 subscripts $\mathrm{i}$ and $\mathrm{t}$ index banks and time in years, respectively; $\mathrm{BP}_{\mathrm{i}, \mathrm{t}}$ is the vector of bank-specific measure of the Spanish banks profitability. $\mathrm{BP}_{\mathrm{i}, \mathrm{t}-1}$ denotes the dependent variables lagged one period. $\alpha$ measures the speed of mean reversion. As Trujillo-Ponce (2013) underscores, a value of $\alpha$ between 0 and 1 implies that bank profitability will ultimately come back to the equilibrium level. NSMP $\mathrm{N}_{\mathrm{i}, \mathrm{t}}$ is the variable that captures the non-standard monetary policies. The rest remains equal to equation $1 .{ }^{12}$

\footnotetext{
${ }^{10}$ Before applying the System-GMM approach, I will perform a dynamic fixed-effects model to check whether the differences between both models are important.

${ }^{11}$ As the estimated asymptotic standard errors of the two-step GMM estimator may be downward biased, I apply the finite sample correction proposed by Windmeijer (2005) to control for this.

${ }^{12}$ The endogeneity of instruments have been tested using the Durbin-Wu-Hausman test, resulting negative.
} 


\section{$5 \quad$ Empirical results}

In this paper, I investigate empirically whether the non-standard monetary policy measures of the Eurosystem have affected bank profitability in Spain with annual panel of 54 banks during the period 2001-2017. Three different measures of bank profitability are employed: ROA, PTOIR and IMR. The results need to be interpreted with caution. Bank profitability may be affected by fiscal and financial factors I have not controlled for.

In section 5.1, I conduct a static fixed-effects regression. In section 5.2, I move from a static context to a dynamic one employing the same methodology as in the previous section. Finally, in section 5.3, I use a system-GMM estimator.

\subsection{Static fixed-effects estimation}

Table 3 presents the first set of results of a static fixed-effects regression for the three measures of bank profitability (ROA, PTOIR, and IMR) in Spain. Columns "A" show the results using Eurosystem total assets as a proxy for non-conventional monetary policies. Columns "B" present the outcomes employing excess reserves as proxy. Columns "C" present the results using the slope of the yield curve as proxy. Results for the three measures of bank profitability are presented in staggered fashion. First, I directly regressed my interest variable with the measure of bank profitability. Second, I controlled for bank-specific factors. Third, I also controlled for macroeconomic conditions.

Starting with ROA (Columns 1A-3C) as proxy for bank profitability, none of the coefficients of Eurosystem total assets are statistically significant. The results are similar when using excess reserves or the slope of the yield curve, when I control for bank-specific factors and macroeconomic conditions. Regarding the PTOIR variable (Columns 4A-6C), when I control for bank-specific factors only, a negative and significant association is found between ECB total assets and the slope of the yield curve. Moreover, if macroeconomic conditions are added to the equation, this relationship remains for Eurosystem total assets but changes its sign for the other variables. Nonetheless, excess reserves do not seem to affect bank profitability, measured as PTOIR. In the third set of regressions (Columns 7A-9C), a positive association between excess reserves, the slope of the yield curve, and the interest margin ratio is found after controlling for both bank-specific factors and macroeconomic conditions.

Overall, employing a static-fixed effects methodology I cannot reject the null hypothesis that non-standard monetary policy measures do not have an impact on bank profitability. Although my analysis of the Spanish banking sector is new, Lambert and Ueda (2014) did not find a conclusive association between bank profitability and non-standard monetary policies in the case of the USA.

\subsection{Dynamic fixed-effects estimation}

The main drawback of the static fixed-effects model I employed for the previous section is that the dynamics of bank profitability, which are regarded as quite relevant 
Table 3: Static fixed-effects estimations

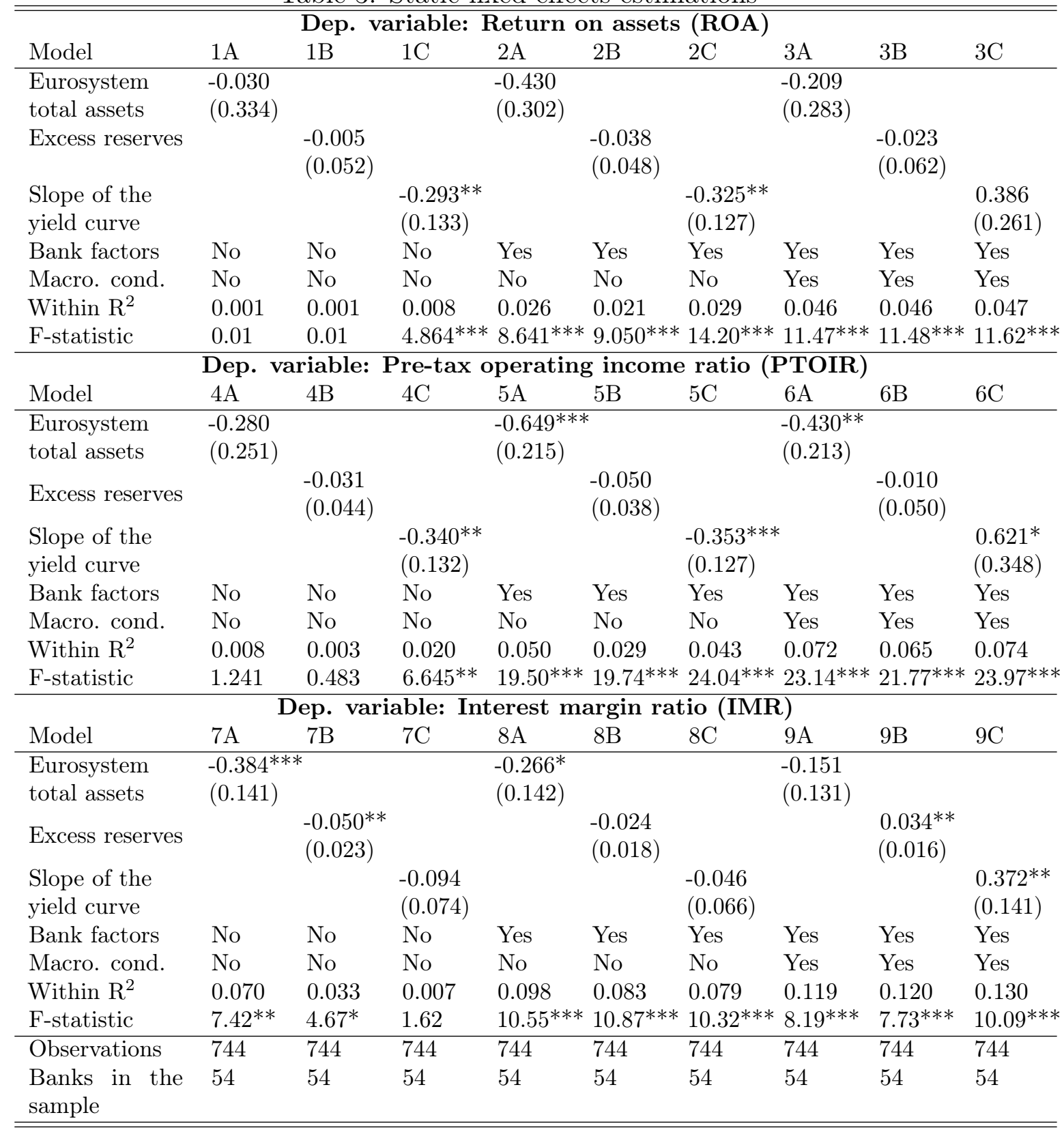

Source: Author's elaboration. Notes: ${ }^{* * *},{ }^{* *}$ and ${ }^{*}$ indicate $1 \%, 5 \%$ and $10 \%$ significance levels respectively. In parentheses are presented robust standard errors clustered by depository institution. Constant included but not reported.

in the literature, were not taken into consideration (Mamatzakis and Bermpei, 2016; Trujillo-Ponce, 2013).

Table 4 reports the empirical estimations including the first lag of the dependent variable (Dep.var $\left.\mathrm{r}_{\mathrm{t}-1}\right)$. All coefficients of the lagged profitability variables are positive and statistically significant, confirming the dynamic character of the model and the importance of controlling for this. There are only minor changes compared to the static fixed-effects specification. When ROA is proxy for bank profitability (models 10A-12C), neither Eurosystem total assets nor excess reserves have any effect on it, no matter which control variables are in play. Only the slope of the yield curve has a 
positive effect. In the case of PTOIR (models 13A-15C), outcomes do not differ at all from Table 3. Finally, non-standard monetary policies' effects on bank profitability, as proxied by excess reserves, are positive and significant at one percent significance level (model 18B) when bank-specific variables and macroeconomic conditions are included for IMR.

Table 4: Dynamic fixed-effects estimations

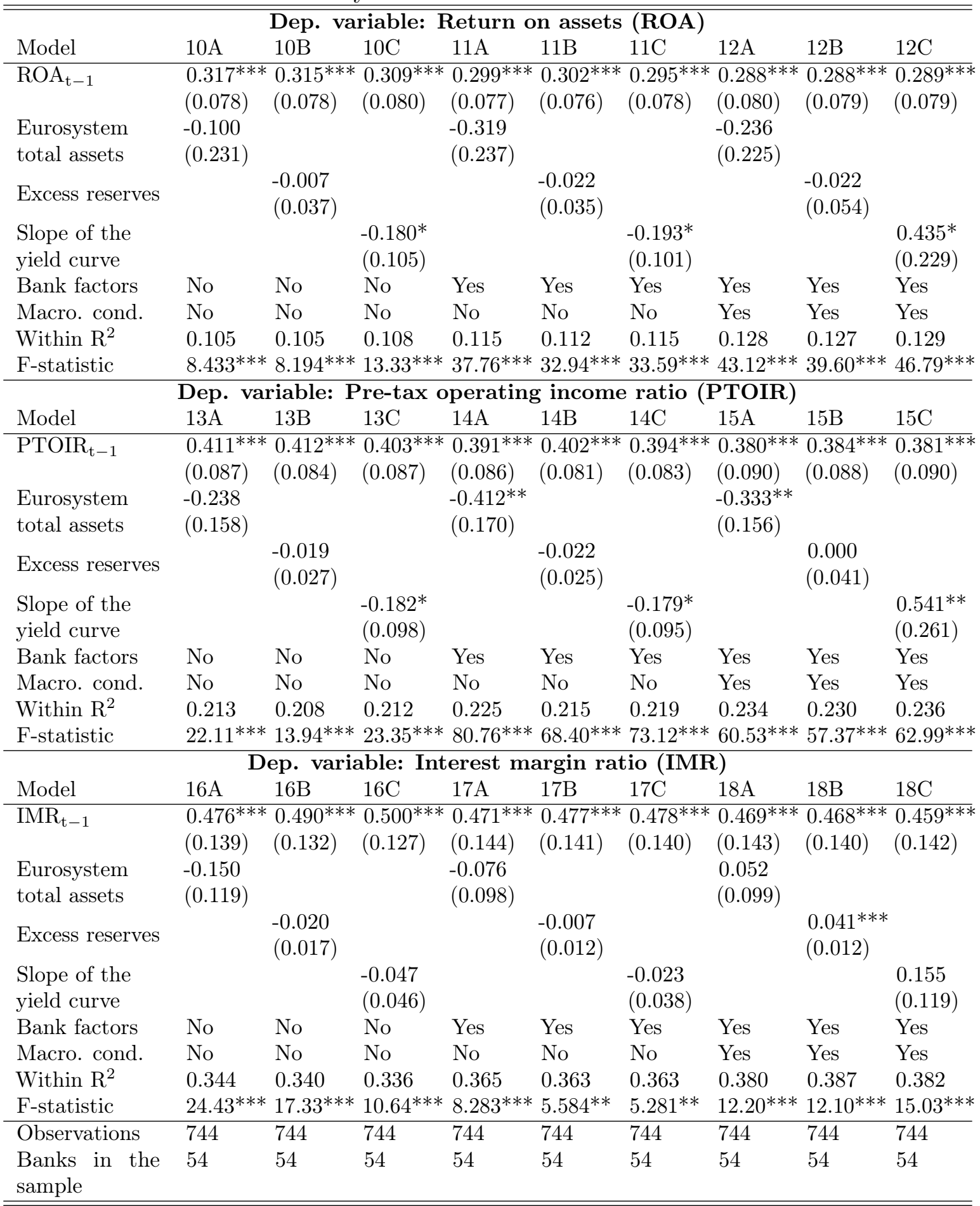

Source: Author's elaboration. Notes: ${ }^{* * *},{ }^{* *}$ and ${ }^{*}$ indicate $1 \%, 5 \%$ and $10 \%$ significance levels respectively. In parentheses are presented robust standard errors clustered by depository institution. Constant included but not reported. 


\subsection{System-GMM estimation}

Table 5 reports the empirical estimations from equation 2, using the system-GMM estimator. ${ }^{13}$ In this case, results are not reported in staggered fashion as in the static and dynamic fixed-effects regressions. This is because the number of instruments employed depends on the number of independent variables, so if I used a different number of instruments for each regression, results would not be comparable. Before commenting the results, the diagnostic test should be analysed. The post-estimation diagnostic tests suggest the following: i) The null hypothesis of the $\operatorname{AR}(2)$ test (Arellano and Bond, 1991) is that the errors in the first difference regression exhibit no second-order serial correlation. The null cannot be rejected in any of the models; ii) The Hansen (1982) J test is a test of the over-identifying restrictions. Under the null hypothesis, there is no correlation between the instruments and the error term. I cannot reject the null in any of the models. In addition, the difference-in-Hansen test will has been performed. It considers whether the difference between the corresponding Hansen statistics is small enough for the null hypothesis not to be rejected. According to the results, the instruments are valid.

All coefficients of the lagged profitability variables (Dep.var $\left.\mathrm{v}_{\mathrm{t}-1}\right)$ are positive and highly statistically significant, confirming the findings of the dynamic fixed-effects model. The value of the lagged ROA is close to 0.20 , indicating a low persistence in bank profitability, while the value of the lagged PTOIR is almost 0.35 , which can be understood as a moderate persistence in bank profitability. In contrast, there is a high persistence in the interest margin ratio variable, whose coefficient is around 0.75. Related papers have found similar results (e.g. Athanasoglu et al. (2008); Trujillo-Ponce (2013)).

Once endogeneity issues have been properly controlled for, no association is found between Spanish bank profitability, as proxied by ROA and PTOIR, and the three measures of non-standard monetary policies (models 19A-21C). All outcomes are in line with the static and the dynamic fixed-effects specifications. It is quite reasonable to believe that the overall effect of non-standard monetary policies on bank profitability is neutral. On the one hand, quantitative easing depresses long-term interest rates and flattens the yield curve, which may reduce bank earnings from maturity transformation activity. This clearly is a negative effect which may also damage bank profitability when deposit rates are close to the zero-lower bound, because depository institutions are reluctant to pass through negative rates to commercial deposits, another negative effect. On the other hand, quantitative easing measures may lower the cost of bank liabilities, not only increasing their net worth but also relaxing their financial constraints. This may generate capital gains because of the increased valuation of bonds in bank portfolios and may lower the cost of debt, both positive effects. Besides, unconventional monetary policies may enhance macroeconomic conditions, boosting the demand for credit and reducing the share of non-performing loans, a positive effect.

\footnotetext{
${ }^{13} \mathrm{I}$ am using from the second to the fifth lag as instruments for the difference and the level equation. I am aware that the higher the number of instruments, the lower the validity of the post-estimation diagnostic tests. As rule of thumb, I have limited the number of instruments to the number of groups in the sample.
} 
Notwithstanding these findings, I found a positive and statistically significant association (model 21B) between IMR and excess reserves. In fact, a one percent increase in excess reserves is associated with a 0.04 percent increase in IMR. Non-standard monetary policies such as quantitative easing flatten the yield curve, which compresses net interest margins. However, non-standard monetary policies mainly affect long-term interest rates, implying that the interest rates on loans decrease more than the interest rates on deposits. In fact, deposit rates may stay unchanged at the zero-lower bound. Because this result is counterintuitive, some robustness checks were performed.

The literature does not provide conclusive evidence about the effects of non-standard monetary policies and bank performance. Whilst Mamatzakis and Bermpei (2016) estimate that the Fed's unconventional monetary policies had a negative effect on US bank performance, Lambert and Ueda (2014) do not find such effects. In the Eurozone, no association has been found between monetary policy easing and lower bank profits (Altavilla et al., 2018). My results follow this trend.

Table 5: System GMM estimation

\begin{tabular}{|c|c|c|c|c|c|c|c|c|c|}
\hline & ROA & & & $\overline{\text { PTOIR }}$ & & & IMR & & \\
\hline Model & $19 \mathrm{~A}$ & 19B & $19 \mathrm{C}$ & $20 \mathrm{~A}$ & $20 \mathrm{~B}$ & $20 \mathrm{C}$ & $21 \mathrm{~A}$ & $21 \mathrm{~B}$ & $21 \mathrm{C}$ \\
\hline Dep.var $_{t-1}$ & $\begin{array}{l}0.191^{*} \\
(0.100)\end{array}$ & $\begin{array}{l}0.195^{*} \\
(0.104)\end{array}$ & $\begin{array}{l}0.193^{* *} \\
(0.093)\end{array}$ & $\begin{array}{l}0.346^{* * *} \\
(0.127)\end{array}$ & $\begin{array}{l}0.322^{* * *} \\
(0.125)\end{array}$ & $\begin{array}{l}0.348^{* * *} \\
(0.131)\end{array}$ & $\begin{array}{l}0.768^{* * *} \\
(0.118)\end{array}$ & $\begin{array}{l}0.751^{* * *} \\
(0.132)\end{array}$ & $\begin{array}{l}0.740^{* * *} \\
(0.122)\end{array}$ \\
\hline $\begin{array}{l}\text { Eurosystem } \\
\text { total assets }\end{array}$ & $\begin{array}{l}0.006 \\
(0.422)\end{array}$ & & & $\begin{array}{l}-0.267 \\
(0.257)\end{array}$ & & & $\begin{array}{l}0.037 \\
(0.077)\end{array}$ & & \\
\hline Excess reserves & & $\begin{array}{l}0.000 \\
(0.066)\end{array}$ & & & $\begin{array}{c}-0.002 \\
(0.046)\end{array}$ & & & $\begin{array}{l}0.045^{* * *} \\
(0.013)\end{array}$ & \\
\hline $\begin{array}{l}\text { Slope of the } \\
\text { yield curve }\end{array}$ & & & $\begin{array}{l}0.331 \\
(0.276)\end{array}$ & & & $\begin{array}{l}0.479 \\
(0.313)\end{array}$ & & & $\begin{array}{l}0.130 \\
(0.099)\end{array}$ \\
\hline Bank factors & Yes & Yes & Yes & Yes & Yes & Yes & Yes & Yes & Yes \\
\hline Macro. cond. & Yes & Yes & Yes & Yes & Yes & Yes & Yes & Yes & Yes \\
\hline AR1 (p-value) & 0.056 & 0.057 & 0.052 & 0.027 & 0.030 & 0.030 & 0.001 & 0.003 & 0.001 \\
\hline AR2 (p-value) & 0.195 & 0.195 & 0.180 & 0.259 & 0.273 & 0.258 & 0.250 & 0.682 & 0.344 \\
\hline Hansen (p-val.) & 0.608 & 0.510 & 0.475 & 0.296 & 0.589 & 0.296 & 0.412 & 0.273 & 0.375 \\
\hline Difference & 0.734 & 0.434 & 0.491 & 0.946 & 0.999 & 0.845 & 0.664 & 0.732 & 0.723 \\
\hline Hansen-test & & & & & & & & & \\
\hline Wald test & $31.59^{* * *}$ & $41.68^{* * *}$ & $23.06^{* * *}$ & $37.77^{* * *}$ & $47.49^{* * *}$ & $43.78^{* * *}$ & $273.8^{* * *}$ & $248.5^{* * *}$ & $373.6^{* * *}$ \\
\hline Observations & 742 & 742 & 742 & 742 & 742 & 742 & 742 & 742 & 742 \\
\hline $\begin{array}{l}\text { Banks in the } \\
\text { sample }\end{array}$ & 54 & 54 & 54 & 54 & 54 & 54 & 54 & 54 & 54 \\
\hline
\end{tabular}

Source: Author's elaboration. Notes: ${ }^{* * *},{ }^{* *}$ and ${ }^{*}$ indicate $1 \%, 5 \%$ and $10 \%$ significance levels respectively. In parentheses are presented robust standard errors clustered by depository institution (corrected by the finite sample correction proposed by Windmeijer (2005)). Constant included but not reported.

\subsection{Robustness analysis}

There may be several reasons to explain the previous findings. It may be an omitted-variable bias. In other words, the model is not properly controlling for bank-specific factors and macroeconomic conditions. A second reason may be that the non-conventional monetary policy measures deployed by the ECB affect each bank in a different way depending on their economies of scale or financial structure. 
The results could also be driven by the creation of new entities as a consequence of the restructuring process of the Spanish banking sector or by the creation of "new virtual entities". I will try to shed light to these issues in the present section, conducting some robustness checks. Finally, non-standard monetary policies may have both positive and negative effects, compensating each other. Trying to isolate this kind of effects may be quite complicated and it is beyond the scope of this paper.

\subsubsection{New control variables}

Trying to capture a possible omitted-variable bias, the system-GMM equation is re-estimated. To do this, I add some variables increasing the number of regressors. Firstly, Athanasoglu et al. (2008) and Trujillo-Ponce (2013) highlight that the relationship between size and profitability may be non-linear. Therefore, the natural logarithm of banks' total assets and their square (BS2) is used to control for this fact. On the other hand, the Great Recession was followed by far-reaching normative and policy changes specifically targeting the banking sector, both internationally and at the national level. At international level, for example, the capital conservation buffer is applied from January 1, 2015, in Spain. The range goes from 0 per cent in 1999-2015, to 0.625 percent in 2016 and 1.25 percent in 2017. At national level, the Spanish saving banks were bailed out in 2012. This bailout was accompanied by a Memorandum of Understanding (MoU), which led to more significant provisioning by Spanish banks, a new reform of the saving banks, higher solvency requirements, and the creation of a "bad bank" (the SAREB) (Maudos and Vives, 2016). This will be captured by a dummy variable.

Table 6 reports the empirical estimations using the system-GMM estimator. As in the previous section, all post-estimation diagnostic tests $(\mathrm{AR}(2)$ test, Hansen test and difference Hansen-test) suggest that the instruments I am using are valid. In this new specification, some of the independent variables have not only the same sign but also the same statistical significance as in Table 5 .

The coefficients of the non-standard monetary policies are not statistically significant when profitability is defined in terms of ROA and PTOIR. Nevertheless, there is a major change with respect to Table 5 . When it is controlled for the square of the natural logarithm of banks' total assets and for regulation, there is not a statistically significant association (model 24B) between IMR and excess reserves. This result is in line with the outcomes of Altavilla et al. (2018).

\subsubsection{Heterogeneous effects}

The non-conventional monetary policy measures deployed by the ECB may affect each bank in a heterogeneous way depending on their economies of scale, financial structure, or funding. So as to deal with this, I will perform some regressions taking into account these characteristics.

First, banks will be classified into three different categories with respect to the level of total assets (bank size): depository institutions in the fourth quartile or "small banks" ( $4^{\text {th }}$ q.BS), banks in the third and the second quartile or "middle size banks" (med.BS), and banks in the first quartile or "big banks" (1 ${ }^{\text {st }}$ q.BS). As an 
Table 6: System GMM with new regressors

\begin{tabular}{|c|c|c|c|c|c|c|c|c|c|}
\hline & ROA & & & PTOIR & & & IMR & & \\
\hline Model & $22 \mathrm{~A}$ & $22 \mathrm{~B}$ & $22 \mathrm{C}$ & $23 \mathrm{~A}$ & $23 \mathrm{~B}$ & $23 \mathrm{C}$ & $24 \mathrm{~A}$ & $24 \mathrm{~B}$ & $24 \mathrm{C}$ \\
\hline & $0.202^{*}$ & $0.196^{*}$ & $0.203^{* *}$ & $0.345^{* * *}$ & $0.327^{* * *}$ & $0.350^{* * *}$ & $0.772^{* * *}$ & $0.771^{* * *}$ & $0.763^{* * *}$ \\
\hline Dep.var $_{t-1}$ & $(0.109)$ & $(0.114)$ & $(0.096)$ & $(0.123)$ & $(0.115)$ & $(0.122)$ & $(0.124)$ & $(0.125)$ & $(0.125)$ \\
\hline $\begin{array}{l}\text { Eurosystem } \\
\text { total assets }\end{array}$ & $\begin{array}{l}-0.079 \\
(0.348)\end{array}$ & & & $\begin{array}{l}-0.491 \\
(0.330)\end{array}$ & & & $\begin{array}{l}-0.001 \\
(0.129)\end{array}$ & & \\
\hline Excess reserves & & $\begin{array}{l}0.159 \\
(0.288)\end{array}$ & & & $\begin{array}{l}0.090 \\
(0.214)\end{array}$ & & & $\begin{array}{l}0.019 \\
(0.086)\end{array}$ & \\
\hline $\begin{array}{l}\text { Slope of the } \\
\text { yield curve }\end{array}$ & & & $\begin{array}{l}0.312 \\
(0.286)\end{array}$ & & & $\begin{array}{l}0.488^{*} \\
(0.266)\end{array}$ & & & $\begin{array}{l}0.089 \\
(0.113)\end{array}$ \\
\hline Bank factors & Yes & Yes & Yes & Yes & Yes & Yes & Yes & Yes & Yes \\
\hline Macro. cond. & Yes & Yes & Yes & Yes & Yes & Yes & Yes & Yes & Yes \\
\hline AR1 (p-value) & 0.055 & 0.056 & 0.052 & 0.025 & 0.025 & 0.026 & 0.001 & 0.001 & 0.001 \\
\hline AR2 (p-value) & 0.210 & 0.236 & 0.190 & 0.262 & 0.307 & 0.261 & 0.370 & 0.428 & 0.497 \\
\hline Hansen (p-val.) & 0.862 & 0.825 & 0.938 & 0.708 & 0.856 & 0.756 & 0.764 & 0.691 & 0.744 \\
\hline Difference & 0.988 & 0.999 & 1.000 & 1.000 & 1.000 & 1.000 & 1.000 & 1.000 & 1.000 \\
\hline \multicolumn{10}{|l|}{ Hansen-test } \\
\hline Wald test & $50.82^{* * *}$ & $50.21 * * *$ & $36.30^{* * *}$ & $82.63^{* * *}$ & $108.3^{* * *}$ & $64.93^{* * *}$ & ${ }^{*} 550.5^{* * *}$ & $464.2^{* * *}$ & $498.7^{* * *}$ \\
\hline Observations & 742 & 742 & 742 & 742 & 742 & 742 & 742 & 742 & 742 \\
\hline $\begin{array}{l}\text { Banks in the } \\
\text { sample }\end{array}$ & 54 & 54 & 54 & 54 & 54 & 54 & 54 & 54 & 54 \\
\hline
\end{tabular}

Source: Author's elaboration. Notes: ${ }^{* * *},{ }^{* *}$ and ${ }^{*}$ indicate $1 \%, 5 \%$ and $10 \%$ significance levels respectively. In parentheses are presented robust standard errors clustered by depository institution (corrected by the finite sample correction proposed by Windmeijer (2005)). Constant included but not reported.

arbitrary measure to classify banks, the year 2015 will be used, a year in which the maximum number of banks are present in the sample. A dummy variable will be created for the small ${ }^{14}$, the big banks group ${ }^{15}$, and the middle size group. ${ }^{16}$ Then, I will interact the non-standard monetary policy variables with the dummy variable of each group. Table 7 reports the empirical estimations (the square of the logarithm of total assets and financial regulation variables haven been included). The post-estimation diagnostic tests suggest that the instruments employed are valid.

Some interesting facts arise. The coefficients of the interaction between non-standard monetary policies measured as excess reserves (EERR) and all groups and bank profitability are not statistically significant. This implies that no association has been found when non-standard monetary policies are captured by excess reserves. In the same way, when they are captured by the slope of the yield curve (SYC), no effect is found with respect to ROA, PTOIR and IMR. On the contrary, non-standard monetary policies proxied by the Eurosystem total assets seems to affect negatively at 10 percent significance level bank profitability captured through PTOIR for banks

\footnotetext{
${ }^{14}$ The "small banks" group is composed by the following 13 banks: A\&G Banca Privada, AndBank España, BNP Paribas España, Banco Alcalá, Banco Europeo de Finanzas, Banco Finantia Sofinloc, Banco Pichincha España, Banco de Depósitos, Banco de la Nacion Argentina, Bank Degroof Petercam Spain, Banque Marocaine du commerce exterieur international, Citibank España and Self Trade Bank.

${ }^{15}$ The "big banks" group is composed by the following 14 banks: Abanca, BBVA, Banco Cooperativo Español, Banco Popular Español, Banco Santander, Banco de Sabadell, Bankia, Bankinter, Caixabank, Ibercaja, Liberbank, Santander Consumer Finance and Unicaja.

${ }^{16}$ The "middle size banks" group is composed by the rest of the depository institutions.
} 
Table 7: System GMM estimation based on total assets classification

\begin{tabular}{|c|c|c|c|c|c|c|c|c|c|}
\hline & \multicolumn{3}{|l|}{ ROA } & \multicolumn{3}{|c|}{ PTOIR } & \multicolumn{3}{|l|}{ IMR } \\
\hline Model & $25 \mathrm{~A}$ & $25 \mathrm{~B}$ & $25 \mathrm{C}$ & $26 \mathrm{~A}$ & $26 \mathrm{~B}$ & $26 \mathrm{C}$ & $27 \mathrm{~A}$ & $27 \mathrm{~B}$ & $27 \mathrm{C}$ \\
\hline & $0.243^{* *}$ & $0.196^{*}$ & $0.203^{* *}$ & $0.414^{* * *}$ & $0.376^{* * *}$ & $0.335^{* *}$ & $0.798^{* * *}$ & $0.782^{* * *}$ & $0.759^{* * *}$ \\
\hline Dep. $\operatorname{var}_{t-1}$ & $(0.104)$ & $(0.102)$ & $(0.089)$ & $(0.117)$ & $(0.111)$ & $(0.130)$ & $(0.098)$ & $(0.120)$ & $(0.106)$ \\
\hline $4^{\text {th }} \mathrm{gBS}$ & -0.358 & & & -0.555 & & & -0.016 & & \\
\hline CNIA $\times 4$ Q.DS & $(0.363)$ & & & $(0.365)$ & & & $(0.102)$ & & \\
\hline $\mathrm{FSTA} \times \operatorname{med} \mathrm{BS}$ & -0.561 & & & $-0.697^{*}$ & & & -0.049 & & \\
\hline ES IA X med.BS & $(0.399)$ & & & $(0.395)$ & & & $(0.116)$ & & \\
\hline $\mathrm{ESTA} \times 1^{\mathrm{st}} \mathrm{q} \cdot \mathrm{BS}$ & $\begin{array}{l}-0.637 \\
(0.478)\end{array}$ & & & $\begin{array}{l}-0.709 \\
(0.496)\end{array}$ & & & $\begin{array}{l}-0.022 \\
(0.137)\end{array}$ & & \\
\hline $\mathrm{EERR} \times 4^{\text {th }} \mathrm{q} \cdot \mathrm{BS}$ & & $\begin{array}{l}0.281 \\
(0.291)\end{array}$ & & & $\begin{array}{l}0.148 \\
(0.244)\end{array}$ & & & $\begin{array}{l}0.026 \\
(0.079)\end{array}$ & \\
\hline $\mathrm{EERR} \times$ med. $\mathrm{BS}$ & & $\begin{array}{l}0.280 \\
(0.325)\end{array}$ & & & $\begin{array}{l}0.161 \\
(0.268)\end{array}$ & & & $\begin{array}{l}0.012 \\
(0.073)\end{array}$ & \\
\hline $\mathrm{EERR} \times 1^{\text {st }} \mathrm{q} \cdot \mathrm{BS}$ & & $\begin{array}{l}0.234 \\
(0.332)\end{array}$ & & & $\begin{array}{l}0.157 \\
(0.247)\end{array}$ & & & $\begin{array}{l}0.033 \\
(0.086)\end{array}$ & \\
\hline $\mathrm{SYC} \times 4^{\mathrm{st}} \mathrm{q} \cdot \mathrm{BS}$ & & & $\begin{array}{l}0.571 \\
(0.457)\end{array}$ & & & $\begin{array}{l}0.500 \\
(0.442)\end{array}$ & & & $\begin{array}{l}0.080 \\
(0.181)\end{array}$ \\
\hline $\mathrm{SYC} \times$ med. $\mathrm{BS}$ & & & $\begin{array}{l}0.335 \\
(0.246)\end{array}$ & & & $\begin{array}{l}0.348 \\
(0.244)\end{array}$ & & & $\begin{array}{l}0.016 \\
(0.150)\end{array}$ \\
\hline $\mathrm{SYC} \times 1^{\mathrm{st}} \mathrm{q} \cdot \mathrm{BS}$ & & & $\begin{array}{l}0.401 \\
(0.251)\end{array}$ & & & $\begin{array}{l}0.382 \\
(0.246)\end{array}$ & & & $\begin{array}{l}0.077 \\
(0.117)\end{array}$ \\
\hline Bank factors & Yes & Yes & Yes & Yes & Yes & Yes & Yes & Yes & Yes \\
\hline Macro. cond. & Yes & Yes & Yes & Yes & Yes & Yes & Yes & Yes & Yes \\
\hline AR1 (p-value) & 0.047 & 0.051 & 0.049 & 0.019 & 0.019 & 0.031 & 0.001 & 0.001 & 0.001 \\
\hline AR2 (p-value) & 0.169 & 0.237 & 0.186 & 0.231 & 0.286 & 0.277 & 0.444 & 0.603 & 0.608 \\
\hline Hansen (p-val.) & 0.831 & 0.702 & 0.888 & 0.701 & 0.697 & 0.814 & 0.622 & 0.461 & 0.430 \\
\hline Difference & 0.790 & 0.680 & 0.986 & 0.898 & 0.884 & 0.992 & 0.998 & 0.948 & 0.908 \\
\hline Hansen-test & & & & & & & & & \\
\hline Wald test & $43.56^{* * *}$ & $63.80 * * *$ & $27.43^{* * *}$ & $76.11^{* * *}$ & $132.4^{* * *}$ & $146.1^{* * *}$ & $901.4^{* * *}$ & $802.7^{* * *}$ & $575.4^{* * *}$ \\
\hline Observations & 742 & 742 & 742 & 742 & 742 & 742 & 742 & 742 & 742 \\
\hline $\begin{array}{l}\text { Banks in the } \\
\text { sample }\end{array}$ & 54 & 54 & 54 & 54 & 54 & 54 & 54 & 54 & 54 \\
\hline
\end{tabular}

Source: Author's elaboration. Notes: ${ }^{* * *},{ }^{* *}$ and ${ }^{*}$ indicate $1 \%, 5 \%$ and $10 \%$ significance levels respectively. In parentheses are presented robust standard errors clustered by depository institution (corrected by the finite sample correction proposed by Windmeijer (2005)). Constant included but not reported.

which belong to the middle size group. Nonetheless, it is not enough evidence to claim that there is any effect. Hence, I should rule out that the previous findings are driven by the chosen year to classify depository institutions. Therefore, I re-estimate the baseline equation taking into account the quartile distribution in 2014 and 2016. Although some banks move from one group to another, the results presented in Table 7 are completely robust: no evidence is found about the relationship between non-standard monetary policies and Spanish banking sector profitability when it is captured through ROA or PTOIR. Results concerning interest margin are also robust. ${ }^{17}$

In Spain, a huge number of households and companies meet their financing needs through direct bank intermediation. Therefore, loans tend to be an important part of the assets of Spanish banks and a remarkable source of revenues (Maudos and Vives,

\footnotetext{
${ }^{17}$ Results are available upon request.
} 
2016). Depository institutions will be classified into the same categories as before but depending on the level of their loan to total assets ratio (LTA): depository institutions in the fourth quartile or "low level of loans to total assets group" ( ${ }^{\text {th }}$ q.LTA), banks in the third and the second quartile (med.LTA), and banks in the first quartile or "high level of loans to total assets group" ( $1^{\text {st }}$ q.LTA). The year 2015 is taken to classify banks. A dummy variable will be created for the low level of loans to total assets group ${ }^{18}$, for the high level of loans to total assets group ${ }^{19}$ and the remaining depository institutions belong to the middle level of loans to total assets group.

Table 8 reports the empirical estimations. ${ }^{20}$ In models 28A, 28B, 29B, 30A, 30B and $30 \mathrm{C}$, no evidence is found of heterogeneous effects of non-standard monetary policies on bank profitability as a function of loan to total assets ratio. Instead, the coefficient of non-standard monetary policies captured through the slope of the yield curve and both ROA and PTOIR of depository institutions in the first quartile is positive and statistically significant at 10 percent. This is not enough evidence to claim that there is a strong relationship between non-standard monetary policies and bank profitability of the Spanish banking sector. Once I re-estimate the baseline equation to discard that results are driven by the chosen year, the outcomes remain without changes. ${ }^{21}$

Third, the funding structure of Spanish banks can be a relevant determinant. Demirgüç-Kunt and Huizinga (2010) argue that those depository institutions which rely more on short-term funding -deposits- tend to suffer less from the risks derived from liquidity problems. Hence, depository institutions will be classified into the same categories as before but depending on the level of their deposits to total assets ratio (DTA). The year 2015 is taken to classify banks. A dummy variable will be created for the low level of deposits to total assets group $\left(4^{\text {th }} \text { q.DTA }\right)^{22}$, for the high level of deposits to total assets group $\left(1^{\text {st }} \mathrm{q} . \mathrm{DTA}\right)^{23}$, and for the medium level (med.DTA). ${ }^{24}$

\footnotetext{
${ }^{18}$ The low level of loans to total assets group is composed by the following 13 banks: Allfunds Bank, Banco Cooperativo Español, Banco Europeo de Finanzas, Banco Finantia Sofinloc, Banco Mediolanum, Banco de Crédito Social Cooperativo, Banco de la Nación Argentina, Citibank, EBN Banco de Negocios, Open Bank, Popular Banca Privada, Santander Securities Services and Self Trade Bank.

${ }^{19}$ The high level of loans to total assets group is composed by the following 13 banks: A\&G Banca Privada, BNP Paribas, Banco Cetelem, Banco de Sabadell, Bancofar, Bankinter, Bankia, Caixabank, Deutsche Bank, Kutxabank, Nuevo Micro Bank, Gargobank and The Bank of Tokyo Mitsubushi UFJ.

${ }^{20}$ The number of instruments employed in the system-GMM is exactly the same as in Table 5.

${ }^{21}$ Results are available upon request.

${ }^{22}$ The low level of deposits to total assets group is composed by the following 13 banks: Allfunds Bank, Aresbank, Banco Cetelem, Banco Europeo de Finanzas, Banco de Crédito Social Cooperativo, Banco de la Nación Argentina, Banque Marocaine du commerce exterieur international, Citibank España, EBN Banco de Negocios, JP Morgan Chase Bank National Association, Nuevo Micro Bank, Santander Consumer Finance and The Bank of Tokyo Mitsubushi UFJ LTD.

${ }^{23}$ The high level of deposits to total assets group is composed by the following 14 banks: Banca March, Banca Pueyo, Banco Inversis, Banco Mediolanum, Banco Pastor, Banco Pichincha España, Bankia, Liberbank, Open Bank, Popular Banca Privada, Santander Securities Services, Self Trade Bank, Targobank and Unicaja.

${ }^{24}$ The medium level of deposits to total assets group is composed by the rest of the depository institutions.
} 
Table 8: System GMM estimation based on loan to total assets classification

\begin{tabular}{|c|c|c|c|c|c|c|c|c|c|}
\hline \multicolumn{4}{|c|}{ ROA } & \multicolumn{3}{|l|}{ PTOIR } & \multicolumn{3}{|l|}{ IMR } \\
\hline Model & $28 \mathrm{~A}$ & $28 \mathrm{~B}$ & $28 \mathrm{C}$ & $29 \mathrm{~A}$ & $29 B$ & $29 \mathrm{C}$ & $30 \mathrm{~A}$ & $30 \mathrm{~B}$ & $30 \mathrm{C}$ \\
\hline & $0.193^{* *}$ & $0.179^{*}$ & $0.192^{* *}$ & $0.334^{* * *}$ & $0.312^{* * *}$ & $0.338^{* * *}$ & $0.730^{* * *}$ & $0.767^{* * *}$ & $0.686^{* * *}$ \\
\hline Dep. $\operatorname{var}_{\mathrm{t}-1}$ & $(0.091)$ & $(0.106)$ & $(0.096)$ & $(0.119)$ & $(0.111)$ & $(0.125)$ & $(0.122)$ & $(0.127)$ & $(0.113)$ \\
\hline \multirow{2}{*}{\multicolumn{2}{|c|}{$\mathrm{ESTA} \times 4^{\text {th }} \mathrm{q} \cdot \operatorname{LTA}_{(0.399)}^{0.031}$}} & & & -0.362 & & & 0.087 & & \\
\hline & & & & $(0.279)$ & & & $(0.108)$ & & \\
\hline \multirow{2}{*}{\multicolumn{2}{|c|}{ ESTA $\times$ med.LTA }} & & & -0.421 & & & 0.023 & & \\
\hline & & & & $(0.276)$ & & & $(0.104)$ & & \\
\hline \multirow{2}{*}{\multicolumn{2}{|c|}{$\mathrm{ESTA} \times 1^{\mathrm{st}} \mathrm{q} \cdot \operatorname{LTA}_{(0.398)}^{-0.155}$}} & & & $-0.461^{*}$ & & & 0.028 & & \\
\hline & & & & $(0.279)$ & & & $(0.107)$ & & \\
\hline \multirow{2}{*}{\multicolumn{2}{|c|}{$\mathrm{EERR} \times 4^{\text {th }} \mathrm{q} \cdot \mathrm{LTA}$}} & 0.356 & & & 0.275 & & & 0.057 & \\
\hline & & $(0.281)$ & & & $(0.252)$ & & & $(0.100)$ & \\
\hline \multirow{2}{*}{\multicolumn{2}{|c|}{ EERR $\times$ med.LTA }} & 0.240 & & & 0.180 & & & 0.037 & \\
\hline & & $(0.250)$ & & & $(0.230)$ & & & $(0.089)$ & \\
\hline \multirow{2}{*}{\multicolumn{2}{|c|}{$\mathrm{EERR} \times 1^{\text {st }} \mathrm{q} \cdot \mathrm{LTA}$}} & 0.160 & & & 0.099 & & & 0.014 & \\
\hline & & $(0.226)$ & & & $(0.203)$ & & & $(0.087)$ & \\
\hline \multirow{2}{*}{\multicolumn{2}{|c|}{$\mathrm{SYC} \times 4^{\text {st }} \mathrm{q} \cdot \mathrm{LTA}$}} & & $0.763^{*}$ & & & $0.813^{*}$ & & & 0.148 \\
\hline & & & $(0.434)$ & & & $(0.431)$ & & & $(0.143)$ \\
\hline \multirow{2}{*}{\multicolumn{2}{|c|}{$\mathrm{SYC} \times$ med.LTA }} & & 0.169 & & & 0.334 & & & -0.010 \\
\hline & & & $(0.317)$ & & & $(0.278)$ & & & $(0.136)$ \\
\hline \multirow{2}{*}{\multicolumn{2}{|c|}{$\mathrm{SYC} \times 1^{\text {st }} \mathrm{q} \cdot \mathrm{LTA}$}} & & 0.188 & & & 0.145 & & & -0.009 \\
\hline & & & $(0.355)$ & & & $(0.313)$ & & & $(0.131)$ \\
\hline Bank factors & Yes & Yes & Yes & Yes & Yes & Yes & Yes & Yes & Yes \\
\hline Macro. cond. & Yes & Yes & Yes & Yes & Yes & Yes & Yes & Yes & Yes \\
\hline AR1 (p-value) & 0.060 & 0.064 & 0.057 & 0.031 & 0.030 & 0.033 & 0.00181 & 0.001 & 0.001 \\
\hline AR2 (p-value) & 0.215 & 0.247 & 0.203 & 0.237 & 0.313 & 0.277 & 0.495 & 0.493 & 0.477 \\
\hline Hansen (p-val.) & 0.996 & 0.993 & 0.998 & 0.976 & 0.969 & 0.943 & 0.976 & 0.936 & 0.771 \\
\hline Difference & 1.000 & 1.000 & 1.000 & 1.000 & 1.000 & 1.000 & 1.000 & 1.000 & 1.000 \\
\hline \multicolumn{10}{|l|}{ Hansen-test } \\
\hline Wald test & $57.22^{* * *}$ & $46.63^{* * *}$ & $58.10^{* * *}$ & $74.79^{* * *}$ & $91.37^{* * *}$ & $80.34^{* * *}$ & $543.9^{* * *}$ & $624.7^{* * *}$ & $412.4^{* * *}$ \\
\hline Observations & 742 & 742 & 742 & 742 & 742 & 742 & 742 & 742 & 742 \\
\hline $\begin{array}{l}\text { Banks in the } \\
\text { sample }\end{array}$ & 54 & 54 & 54 & 54 & 54 & 54 & 54 & 54 & 54 \\
\hline
\end{tabular}

Source: Author's elaboration. Notes: ${ }^{* * *},{ }^{* *}$ and ${ }^{*}$ indicate $1 \%, 5 \%$ and $10 \%$ significance levels respectively. In parentheses are presented robust standard errors clustered by depository institution (corrected by the finite sample correction proposed by Windmeijer (2005)). Constant included but not reported.

Table 9 shows the results. Non-standard monetary policies captured through excess reserves do not seem to affect any of the bank profitability measures. When non-standard monetary policy measures are proxied by the Eurosystem total assets, a 5 percent statistically significance association is found between them and PTOIR for those banks which belong to the medium level of deposits to total assets (second and third quartile) group and to the high level of deposits to total assets group (first quartile). When they are proxied by the slope of the yield curve, a 10 percent statistically significance association is found between them and ROA and PTOIR for the fourth quartile group of banks. Nevertheless, these relationships vanish if the chosen year changes. ${ }^{25}$ Therefore, none of the standard monetary policy measures are statistically significant.

\footnotetext{
${ }^{25}$ Results available upon request.
} 
Table 9: System GMM Estimation based on deposits to total assets classification

\begin{tabular}{|c|c|c|c|c|c|c|c|c|c|}
\hline \multicolumn{4}{|c|}{ ROA } & \multicolumn{3}{|l|}{ PTOIR } & \multicolumn{3}{|l|}{ IMR } \\
\hline Model & $31 \mathrm{~A}$ & $31 \mathrm{~B}$ & $31 \mathrm{C}$ & $32 \mathrm{~A}$ & $32 \mathrm{~B}$ & $32 \mathrm{C}$ & $33 \mathrm{~A}$ & $33 \mathrm{~B}$ & $33 \mathrm{C}$ \\
\hline & $0.224^{* *}$ & $0.204^{* *}$ & $0.192^{* *}$ & $0.375^{* * *}$ & $0.353^{* * *}$ & $0.312^{* * *}$ & $0.745^{* * *}$ & $0.733^{* * *}$ & $0.746^{* * \lambda}$ \\
\hline Dep.var -1 & $(0.098)$ & $(0.096)$ & $(0.088)$ & $(0.123)$ & $(0.111)$ & $(0.118)$ & $(0.104)$ & $(0.109)$ & $(0.121)$ \\
\hline $\left.\mathrm{ESTA} \times 4^{\text {th }} \mathrm{q} \cdot \mathrm{D}\right]$ & $\begin{array}{l}0.027 \\
(0.133)\end{array}$ & & & $\begin{array}{l}-0.196 \\
(0.125)\end{array}$ & & & $\begin{array}{l}-0.042 \\
(0.048)\end{array}$ & & \\
\hline $\mathrm{ESTA} \times \operatorname{med} . \mathrm{D} T$ & $\begin{array}{l}0.114 \\
(0.162)\end{array}$ & & & $\begin{array}{l}-0.294^{* *} \\
(0.131)\end{array}$ & & & $\begin{array}{l}-0.071 \\
(0.050)\end{array}$ & & \\
\hline $\mathrm{ESTA} \times 1^{\mathrm{st}} \mathrm{q} \cdot \mathrm{DT}$ & $\begin{array}{c}-0.137 \\
(0.144)\end{array}$ & & & $\begin{array}{l}-0.284^{* *} \\
(0.129)\end{array}$ & & & $\begin{array}{l}-0.066 \\
(0.044)\end{array}$ & & \\
\hline $\mathrm{EERR} \times 4^{\text {th }} \mathrm{q} \cdot \mathrm{D}^{\mathrm{r}}$ & & $\begin{array}{l}0.082 \\
(0.155)\end{array}$ & & & $\begin{array}{l}0.005 \\
(0.120)\end{array}$ & & & $\begin{array}{l}-0.011 \\
(0.040)\end{array}$ & \\
\hline EERR $\times$ med. $D^{\prime}$ & & $\begin{array}{l}-0.122 \\
(0.149)\end{array}$ & & & $\begin{array}{l}-0.152 \\
(0.142)\end{array}$ & & & $\begin{array}{l}-0.034 \\
(0.053)\end{array}$ & \\
\hline $\mathrm{EERR} \times 1^{\mathrm{st}} \mathrm{q} \cdot \mathrm{D}^{\prime}$ & & $\begin{array}{l}-0.105 \\
(0.143)\end{array}$ & & & $\begin{array}{l}-0.119 \\
(0.125)\end{array}$ & & & $\begin{array}{l}-0.040 \\
(0.045)\end{array}$ & \\
\hline $\mathrm{SYC} \times 4^{\mathrm{st}} \mathrm{q} \cdot \mathrm{DT}$ & & & $\begin{array}{l}0.755^{*} \\
(0.436)\end{array}$ & & & $\begin{array}{l}0.676^{*} \\
(0.401)\end{array}$ & & & $\begin{array}{l}0.075 \\
(0.101)\end{array}$ \\
\hline $\mathrm{SYC} \times \operatorname{med} . \mathrm{DT}$ & & & $\begin{array}{l}0.118 \\
(0.318)\end{array}$ & & & $\begin{array}{l}0.114 \\
(0.231)\end{array}$ & & & $\begin{array}{l}-0.014 \\
(0.181)\end{array}$ \\
\hline $\mathrm{SYC} \times 1^{\mathrm{st}} \mathrm{q} \cdot \mathrm{DT}$ & & & $\begin{array}{l}0.184 \\
(0.255)\end{array}$ & & & $\begin{array}{l}0.318 \\
(0.282)\end{array}$ & & & $\begin{array}{l}-0.066 \\
(0.142)\end{array}$ \\
\hline Bank factors & Yes & Yes & Yes & Yes & Yes & Yes & Yes & Yes & Yes \\
\hline Macro. cond. & Yes & Yes & Yes & Yes & Yes & Yes & Yes & Yes & Yes \\
\hline AR1 (p-value) & 0.047 & 0.049 & 0.051 & 0.019 & 0.020 & 0.027 & 0.001 & 0.001 & 0.001 \\
\hline AR2 (p-value) & 0.174 & 0.173 & 0.178 & 0.229 & 0.225 & 0.283 & 0.473 & 0.524 & 0.712 \\
\hline Hansen (p-val.) & 0.865 & 0.818 & 0.967 & 0.894 & 0.716 & 0.780 & 0.537 & 0.474 & 0.578 \\
\hline Difference & 0.775 & 0.993 & 1.000 & 1.000 & 0.990 & 0.978 & 0.829 & 0.918 & 0.890 \\
\hline Hansen-test & & & & & & & & & \\
\hline Wald test & $60.97 * * *$ & $40.06^{* * *}$ & $41.40^{* * *}$ & $138.9^{* * *}$ & $279.4^{* * *}$ & $120.5^{* * *}$ & $747.2^{* * *}$ & $511.0 * * *$ & $608.2^{* *}$ \\
\hline Observations & 742 & 742 & 742 & 742 & 742 & 742 & 742 & 742 & 742 \\
\hline $\begin{array}{l}\text { Banks in the } \\
\text { sample }\end{array}$ & 54 & 54 & 54 & 54 & 54 & 54 & 54 & 54 & 54 \\
\hline
\end{tabular}

Source: Author's elaboration. Notes: ${ }^{* * *},{ }^{* *}$ and ${ }^{*}$ indicate $1 \%, 5 \%$ and $10 \%$ significance levels respectively. In parentheses are presented robust standard errors clustered by depository institution (corrected by the finite sample correction proposed by Windmeijer (2005)). Constant included but not reported.

\subsubsection{Without new entities}

Finally, in order to avoid that the results are driven by the creation of new entities as a consequence of the restructuring process of the Spanish banking sector, I exclude the following banks from the sample: Abanca (2011), Banco de Crédito Social Cooperativo (2014), Bankia (2011), Caixabank (2010), Ibercaja (2011), Kutxabank (2012), Liberbank (2011), Unicaja (2011). All of the previous banks were created merging savings banks in different regions of the Spanish geography. Table 10 reports the empirical estimations for this new sample using the system-GMM estimator. The main results do not differ from those reported in Table 5. The first lag of all profitability variables is statistically significant and non-standard monetary policies do not seem to have any effect on bank profitability when it is proxied by ROA, PTOIR or the interest margin. 
Table 10: Excluding new entities. System GMM estimation

\begin{tabular}{|c|c|c|c|c|c|c|c|c|c|}
\hline \multirow[b]{2}{*}{ Model } & \multicolumn{3}{|l|}{ ROA } & \multicolumn{3}{|c|}{ PTOIR } & \multicolumn{3}{|l|}{ IMR } \\
\hline & $34 \mathrm{~A}$ & $34 \mathrm{~B}$ & $34 \mathrm{C}$ & $35 \mathrm{~A}$ & $35 \mathrm{~B}$ & $35 \mathrm{C}$ & $36 \mathrm{~A}$ & $36 \mathrm{~B}$ & $36 \mathrm{C}$ \\
\hline & $0.210^{* *}$ & $0.211^{*}$ & $0.211^{*}$ & $0.397^{* * *}$ & $0.412^{* * *}$ & $0.403^{* * *}$ & $0.780^{* * *}$ & $0.793^{* * *}$ & $0.775^{* * *}$ \\
\hline $\mathrm{BP} t-1$ & $(0.107)$ & $(0.111)$ & $(0.115)$ & $(0.124)$ & $(0.131)$ & $(0.120)$ & $(0.120)$ & $(0.110)$ & $(0.113)$ \\
\hline Eurosystem & 0.106 & & & -0.184 & & & -0.067 & & \\
\hline Total Assets & $(0.404)$ & & & $(0.241)$ & & & $(0.112)$ & & \\
\hline Excess & & 0.258 & & & 0.239 & & & 0.011 & \\
\hline Reserves & & $(0.324)$ & & & $(0.254)$ & & & $(0.099)$ & \\
\hline $\begin{array}{l}\text { Slope of the } \\
\text { yield curve }\end{array}$ & & & $\begin{array}{l}0.067 \\
(0.269)\end{array}$ & & & $\begin{array}{l}0.200 \\
(0.208)\end{array}$ & & & $\begin{array}{l}0.115 \\
(0.121)\end{array}$ \\
\hline Bank factors & Yes & Yes & Yes & Yes & Yes & Yes & Yes & Yes & Yes \\
\hline Macro. cond. & Yes & Yes & Yes & Yes & Yes & Yes & Yes & Yes & Yes \\
\hline AR1 (p-value) & 0.076 & 0.077 & 0.076 & 0.058 & 0.055 & 0.056 & 0.001 & 0.001 & 0.001 \\
\hline AR2 (p-value) & 0.203 & 0.214 & 0.209 & 0.194 & 0.205 & 0.193 & 0.186 & 0.184 & 0.189 \\
\hline Hansen (p-val.) & 0.961 & 0.952 & 0.991 & 0.897 & 0.918 & 0.805 & 0.893 & 0.857 & 0.925 \\
\hline Difference & 0.998 & 0.993 & 1.000 & 1.000 & 1.000 & 1.000 & 0.909 & 0.947 & 0.999 \\
\hline Hansen-test & & & & & & & & & \\
\hline Wald test & $48.15^{* * *}$ & $60.48^{* * *}$ & $60.67^{* * *}$ & $116.7^{* * *}$ & $119.3^{* * *}$ & $103.3^{* * *}$ & $426.5^{* * *}$ & $380.3^{* * *}$ & $343.2^{* * *}$ \\
\hline Observations & 659 & 659 & 659 & 659 & 659 & 659 & 659 & 659 & 659 \\
\hline $\begin{array}{l}\text { Banks in the } \\
\text { sample }\end{array}$ & 46 & 46 & 46 & 46 & 46 & 46 & 46 & 46 & 46 \\
\hline
\end{tabular}

Source: Author's elaboration. Notes: ${ }^{* * *},{ }^{* *}$ and ${ }^{*}$ indicate $1 \%, 5 \%$ and $10 \%$ significance levels respectively. In parentheses are presented robust standard errors clustered by depository institution (corrected by the finite sample correction proposed by Windmeijer (2005). Constant included but not reported.

\section{Conclusion}

The traditional financial intermediation model predominates in Spain. This feature makes the Spanish banking sector, along with the rest of the Euro area banking system, cornerstones of the Eurosystem monetary policy. However, although the financial crisis eroded Spanish bank profitability, it has not recovered, on average, since then. Financial institutions attribute this to negative effects that some non-standard monetary policies may have on their profits. A sound banking sector is crucial for a developed economy. In fact, effective financial intermediation and sound financial institutions are clearly linked to a healthy economy (Camdessus, 1997). Hence, this paper empirically investigates whether the non-standard monetary policy measures implemented by the Eurosystem have affected the profitability of the Spanish banking sector. Understanding these effects, especially their potential negative impact, has important policy implications.

Controlling for bank-specific factors and macroeconomic conditions, no effect of non-standard monetary policy measures on bank profitability is found through Eurosystem total assets, excess reserves, or the yield curve slope. This can be explained by the different positive and negative impacts of non-standard monetary policies on bank profitability. Quantitative easing measures lower the cost of bank liabilities, not only increasing their net worth but also relaxing their financial constraints. In addition, capital gains may be generated by the increased valuation of bonds in bank portfolios, which may lower the cost of debt and improve the macroeconomic outlook, which may boost the demand for credit and reduce non-performing 
loans and loan loss provisioning (positive effects). Nonetheless, quantitative easing depresses long-term interest rates and flattens the yield curve, reducing bank earnings from maturity transformation activity. It can also damage bank profitability when deposit rates are near the zero-lower bound, because financial institutions may be reluctant to pass through negative rates to commercial deposits, at least in Spain. The neutral result is robust to different specifications and robustness checks and is in line with the results of Altavilla et al. (2018).

The literature has established three different channels through which non-standard monetary policies might have an impact on the banking sector: the portfolio rebalancing channel, the liquidity channel, and the signalling channel. It is likely that some effects just offset each other. Disentangling these effects is an avenue for further research. 


\section{References}

Abidi, N. and Miquel-Flores, I. (2018). Who benefits from the corporate QE? A regression discontinuity design approach. ECB Working Paper, (2145).

Acharya, V. V., Eisert, T., Eufinger, C., and Hirsch, C. (2019). Whatever It Takes: The Real Effects of Unconventional Monetary Policy. Review of Financial Studies, 32(9):3366-3411.

Altavilla, C., Boucinha, M., and Peydró, J.-L. (2018). Monetary Policy and Bank Profitability in a Low Interest Rate Environment. Economic Policy, 33(96):531-586.

Ambler, S. and Rumler, F. (2019). The Effectiveness of Unconventional Monetary Policy Announcements in the Euro Area: An Event and Econometric Study. Journal of International Money and Finance, 94:48 - 61.

Arellano, M. and Bond, S. (1991). Some Tests of Specification for Panel Data: Monte Carlo Evidence and an Application to Employment Equations. The Review of Economic Studies, 58(2):277-297.

Arellano, M. and Bover, O. (1995). Another Look at the Instrumental Variable Estimation of Error-Components Models. Journal of Econometrics, 68(1):29 - 51.

Athanasoglu, P., Brissimis, S., and Delis, M. (2008). Bank-specific, Industry-specific and Macroeconomic Determinats of Bank Profitability. Journal of International Financial Markets, Institutions and Money, 18(2):121-136.

Avalos, F. and Mamatzakis, E. (2018). Euro Area Unconventional Monetary Policy and Bank Resilience. BIS Working Papers, (754).

Baltagi, B. (2008). Econometric Analysis of Panel Data. John Wiley \& Sons.

Bikker, J. and Hu, H. (2002). Cyclical Patterns in Profits, Provisioning and Lending of Banks and Procyclicality of the New Basel Requirements. BNL Quarterly Review, 221:143-175.

Blot, C., Creel, J., Hubert, P., and Labondance, F. (2019). The Role of ECB Monetary Policy and Financial Stress on Eurozone Sovereign Yields. Empirical Economics, pages 1-23.

Blundell, R. and Bond, S. (1998). Initial Conditions and Moment Restrictions in Dynamic Panel Data Models. Journal of Econometrics, 87(1):115 - 143.

Borio, C., Gambacorta, L., and Hofmann, B. (2017). The Influence of Monetary Policy on Bank Profitability. International Finance, 20:48-63.

Bowdler, C. and Radia, A. (2012). Unconventional Monetary Policy: The Assessment. Oxford Review of Economic Policy, 28(4):603-621.

Brunner, K. and Meltzer, A. H. (1972). Money, Debt, and Economic Activity. Journal of Political Economy, 80(5):951-977.

Camdessus, M. (1997). The Challenges of a Sound Banking System. Luncheon Address at the Seventh Central Banking Seminar. 
Chodorow-Reich, G. (2014). Effects of Unconventional Monetary Policy on Financial Institutions. Brookings Papers on Economic Activity, pages 155-204.

Darvas, Z. and Pichler, D. (2018). Excess Liquidity and Bank Lending Risks in the Euro Area. Policy Contribution Issue, (16).

De Luigi, C., Feldkircher, M., Poyntner, P., Schuberth, H., et al. (2019). Effects of the ECB's Unconventional Monetary Policy on Real and Financial Wealth. Vienna University of Economics and Business Working Paper, (286).

Dell'Ariccia, G., Rabanal, P., and Sandri, D. (2018). Unconventional Monetary Policies in the Euro Area, Japan, and the United Kingdom. The Journal of Economic Perspectives, 32(4):147-172.

Demirgüç-Kunt, A. and Huizinga, H. (1999). Determinants of Commercial Bank Interest Margins and Profitability: Some International Evidence. The World Bank EconomicReview, 13(2):379-408.

Demirgüç-Kunt, A. and Huizinga, H. (2000). Financial Structure and Bank Profitability. World Bank Policy Research Working Paper, (2430).

Demirgüç-Kunt, A. and Huizinga, H. (2010). Bank Activity and Funding Strategies: The impact on Risk and Returns. Journal of Financial Economics, 98(3):626-650.

English, W. B. (2002). Interest Rate Risk and Bank Net Interest Margins. BIS Quarterly Review, 10:67-82.

English, W. B., Van den Heuvel, S., and Zakrajsek, E. (2012). Interest Rate Risk and Bank Equity Valuations. Federal Reserve Finance and Economics Discussion Series, (2012-26).

Eser, F. and Schwaab, B. (2013). Assessing Asset Purchases within the ECB's Securities Markets Programme. ECB Working Paper, (1587).

Ferrando, A., Popov, A., and Udell, G. F. (2019). Do SMEs Benefit from Unconventional Monetary Policy and How? Microevidence from the Eurozone. Journal of Money, Credit and Banking, 51(4):895-928.

Flannery, M. (1981). Market Interest Rates and Commercial Bank Profitability: An Empirical Investigation. The Journal of Finance, 36(5):1085-1101.

Freixas, X., Laeven, L., and Peydró, J.-L. (2015). Systemic Risk, Crises, and Macroprudential Regulation. MIT Press.

Gambacorta, L., Hofmann, B., and Peersman, G. (2014). The Effectiveness of Unconventional Monetary Policy at the Zero Lower Bound: A Cross-Country Analysis. Journal of Money, Credit and Banking, 46:615-642.

García-Herrero, A., Gavilá, S., and Santabárbara, D. (2009). What Explains the Low Profitability of Chinese Banks. Journal of Banking \& Finance, 33:2080-2092.

García-Marco, T. and Robles-Fernández, M. D. (2008). Risk-taking Behaviour and Ownership in the Banking Industry: The Spanish Evidence. Journal of Economics and Business, 60:332-354. 
Haitsma, R., Unalmis, D., and De Haan, J. (2016). The Impact of the ECB's Conventional and Unconventional Monetary Policies on Stock Markets. Journal of Macroeconomics, 48:101 - 116.

Hancock, D. (1985). Bank Profitability, Interest Rates, and Monetary Policy. Journal of Money, Credit and Banking, 17(2):189-202.

Hansen, L. P. (1982). Large Sample Properties of Generalized Method of Moments Estimators. Econometrica, 50(4):1029-1054.

Hartmann, P. and Smets, F. (2018). The First Twenty of the European Central Bank: Monetary Policy. ECB Working Paper, (2219).

Hausman, J. A. (1978). Specification Tests in Econometrics. Econometrica, 46(6):1251-1271.

Heider, F., Saidi, F., and Schepens, G. (2018). Life Below Zero: Bank Lending Under Negative Policy Rates. ECB Working Paper, (2173).

Jimenez, G., López, J., and Saurina, J. (2013). How Does Competition Affect Bank Risk-taking? Journal of Financial Stability, 9(2):185-195.

Keister, T. and McAndrews, J. (2009). Why are Banks Holding so Many Excess Reserves. Current Issues in Economics and Finance, 15(8):1-10.

Knapp, M., Gart, A., and Chaudhry, M. (2006). The Impact of Mean Reversion of Bank Profitability on Post-Merger Performance in the Banking Industry. Journal of Banking \& Finance, 30(12):3503-3517.

Kuttner, K. (2018). Outside the Box: Unconventional Monetary Policy in the Great Recession and Beyond. Journal of Economic Perspectives, 32(4):121-46.

Lambert, F. and Ueda, K. (2014). The Effects of Unconventional Monetary Policies on Bank Soundness. International Monetary Fund Working Paper, (14/152).

Lopez, J. A., Rose, A. K., and Spiegel, M. M. (2018). Why Have Negative Nominal Interest Rates Had Such a Small Effect on Bank Performance? Cross Country Evidence. Federal Reserve Bank of San Francisco. Working Paper Series.

Mamatzakis, E. and Bermpei, T. (2016). What is the Effect of Unconventional Monetary Policy on Bank Performance. Journal of International Money and Finance, 67:239-263.

Maudos, J. (2012). El Impacto de la Crisis en el Sector Bancario Español. Cuadernos de Información Económica, 226:155-163.

Maudos, J. and Vives, X. (2016). Banking in Spain. In Beck, T. and Casu, B., editors, The Palgrave Handbook of European Banking, pages 567-601. Springer.

McKay, A., Nakamura, E., and Steinsson, J. (2016). The Power of Forward Guidance Revisited. American Economic Review, 106(10):3133-58.

Mester, L. (1993). Efficiency in the Savings and Loan Industry. Journal of Banking Ef Finance, 17(2-3):267-287. 
Montecino, J. and Epstein, G. (2014). Have Large Scale Asset Purchases Increased Bank Profits? Institute for New Economic Thinking Working Paper Series, (5).

Pasiouras, F. and Kosmidou, K. (2007). Factors Influencing the Profitability of Domestic and Foreign Commercial Banks in the European Union. Research in International Business and Finance, 21:222-237.

Peersman, G. (2011). Macroeconomic Effects of Unconventional Monetary Policy in the Euro Area. ECB Working Paper, (1397).

Perry, P. (1992). Do Banks Gain or Lose From Inflation. Journal of Retail Banking, 14:25-30.

Petria, N., Capraru, B., and Ihnatov, I. (2015). Determinats of Banks Profitability: Evidence from EU 27 Banking Systems. Procedia Economics and Finance, $20: 58-524$.

Revell, J. (1979). Inflation and Financial Institutions. Financial Times.

Samuelson, P. A. (1945). The Effect of Interest Rate Increases on the Banking System. The American Economic Review, 35(1):16-27.

Scotti, C., Rogers, J. H., and Wright, J. H. (2014). Evaluating Asset-Market Effects of Unconventional Monetary Policy: A Multi-country Review. Economic Policy, 29(80):749-799.

Short, B. (1979). The Relationship Between Commercial Bank Profit Rates and Banking Concentration in Canada, Canada and Japan. Journal of Banking and Finance, 3:209-219.

Szczerbowicz, U. (2015). The ECB Unconventional Monetary Policies: Have They Lowered Market Borrowing Costs for Banks and Governments. International Journal of Central Banking, 11(4):91-127.

Tobin, J. (1963). An Essay on the Principles of Debt Management. Cowles Foundation for Research in Economics at Yale University New Haven.

Tobin, J. (1969). A General Equilibrium Approach to Monetary Theory. Journal of Money, Credit and Banking, 1(1):15-29.

Todd, W. (2013). The Problem of Excess Reserves, Then and Now. Levy Economics Institute of Bard College Working Paper, (763).

Trujillo-Ponce, A. (2013). What Determines the Profitability of Banks? Evidence from Spain. Accounting and Finance, 53:561-586.

Windmeijer, F. (2005). A Finite Sample Correction for the Variance of Linear Efficient Two-Step GMM Estimators. Journal of Econometrics, 126(1):25 - 51. 


\section{A Appendix}

\section{A.1 Data cleaning}

In this section I will explain how the database has been built. Two main statistical sources have been employed: the Spanish Banking Association and the Spanish Stock Market Commission (CNMV). From the Spanish Banking Association I have gathered annual data from the Spanish Banking Industry Statistical Yearbook (SBISY) for a period that goes from 1999 to 2017. Since the SBISY does not include those new entities created after 2010, data from the CNMV is employed. This data is collected from the audits of each bank that were presented to the CNMV each year. An important feature of this data is that it is presented in both consolidated and non-consolidated data. Given that some Spanish depository institutions are major global firms (e.g. Banco Santander or BBVA) and they are therefore exposed to different markets, non-consolidated data is preferred.

The economic and financial crisis led to a massive restructuring process of the Spanish banking sector. Some saving banks in trouble were merged to each other in order to create new entities (e.g. Bankia (merging Caja Madrid, Bancaja, Caja de Canarias, Caja de Ávila, Caixa Laietana, Caja Segovia and Caja Rioja), Abanca (merging Caixa Galicia and Caixanova), Liberbank (merging Cajastur, Caja de Extremadura, Caja de Castilla-La Mancha and Caja de Cantabria), Kutxabank (Bilbao Bizkaia Kutxa, Caja Vital and Kutxa).). The rest were absorbed by the main Spanish commercial banks (Banco Santander, Banco Popular, BBVA and Banco Sabadell). Hence, new "virtual-entities" have been constructed adding balance sheets over the 1999-2017 period in order to control for mergers and acquisitions. Tables A1 and A2 shows this process in detail. All banks which declared bankruptcy before 2017 have been removed from the sample.

Table A1: Mergers and acquisitions

\begin{tabular}{lll}
\hline \hline Main bank & Absorbed/acquired bank & Year \\
\hline Banco Santander & Banco de Desarrollo Económico Español & 2003 \\
& Banco de Vitoria & 2004 \\
& Banco Banif & 2013 \\
& Banco Español de Crédito (BANESTO) & 2013 \\
\hline Banco Popular & Banco de Castilla & 2008 \\
& Banco de Crédito Balear & 2008 \\
& Banco de Galicia & 2008 \\
& Banco de Vasconia & 2008 \\
& Banco de Andalucía & 2009 \\
\hline BBVA & BBVA Privanzabanco & 2003 \\
& Banco de Crédito Local de España & 2009 \\
& Finanzia, Banco de Crédito & 2011 \\
& Unoe Bank S.A. & 2016 \\
& Banco Depositario BBVA & 2016 \\
\hline Banco Caixa Geral & Banco Extremadura & 2001 \\
& Banco Simeón & 2002 \\
\hline Banco Inversis & Bancoval Securities Services & 2017 \\
\hline \hline Source: Spanish Banking Industry Statistical 2017 Yearbook.
\end{tabular}


Table A2: Mergers and acquisitions (Continuation)

\begin{tabular}{|c|c|c|}
\hline Main bank & Absorbed/acquired bank & Year \\
\hline \multirow[t]{7}{*}{ Banco Sabadell } & Soldbank & 2001 \\
\hline & Banco Herrero & 2002 \\
\hline & Activobank & 2003 \\
\hline & Banco de Asturias & 2003 \\
\hline & Banco Atlántico & 2004 \\
\hline & Banco Urquijo & 2006 \\
\hline & Banco CAM & $2012^{*}$ \\
\hline \multirow[t]{5}{*}{ Caixabank } & Microbank de la Caixa & 2011 \\
\hline & Banca Cívica & 2012 \\
\hline & Banco de la Pequeña y la Mediana Empresa & 2012 \\
\hline & Banco de Valencia & 2013 \\
\hline & Barclays Bank & 2015 \\
\hline \multirow[t]{7}{*}{ Bankia } & Caja Madrid & $2010^{*}$ \\
\hline & Bancaja & $2010^{*}$ \\
\hline & Caja de Canarias & $2010^{*}$ \\
\hline & Caja de Ávila & $2010^{*}$ \\
\hline & Caixa Laietana & $2010^{*}$ \\
\hline & Caja Segovia & $2010^{*}$ \\
\hline & Caja Rioja & $2010^{*}$ \\
\hline \multirow[t]{4}{*}{ Liberbank } & Cajastur & $2011^{*}$ \\
\hline & Caja de Extremadura & $2011^{*}$ \\
\hline & Caja de Castilla-La Mancha & $2011^{*}$ \\
\hline & Caja de Cantabria & $2011^{*}$ \\
\hline \multirow[t]{2}{*}{ Abanca } & Caixa Galicia & $2011^{*}$ \\
\hline & Caixanova & $2011^{*}$ \\
\hline \multirow[t]{3}{*}{ Kutxabank } & Bilbao Bizkaia Kutxa & $2011^{*}$ \\
\hline & Caja Vital & $2011^{*}$ \\
\hline & Kutxa & $2011^{*}$ \\
\hline
\end{tabular}

$\overline{\text { Source: Spanish Banking Industry Statistical } 2017 \text { Yearbook. }{ }^{*} \text { Data retrieved from the Spanish }}$ Stock Market Commission.

Besides, I have had to keep track of all changes in bank names during the 1999-2017 period. Table A3 show the changes in bank names. 
Table A3: Changes in bank names

\begin{tabular}{|c|c|c|}
\hline Current name & Previous name & Year* \\
\hline Allfunds Bank & Banco de Sevilla & 2000 \\
\hline Aresbank & Banco Árabe Español & 2008 \\
\hline Banco Caixa Geral & Banco Luso Español & 2002 \\
\hline $\begin{array}{ll}\text { Banco Bilbao } & \text { Vizcaya } \\
\text { Argentaria (BBVA) } & \end{array}$ & Banco Bilbao Vizcaya & 2000 \\
\hline Banco Cetelem & Banco Fimestic & 2002 \\
\hline Banco Finantia Sofinloc & Banco Esfinge & 2002 \\
\hline Banco Inversis & Banco Inversis Net & 2008 \\
\hline Banco Mediolanum & $\begin{array}{l}\text { Banco de Finanzas e } \\
\text { (FIBANC) }\end{array}$ & 2012 \\
\hline Banco Santander & Banco Santander Central Hispano & 2007 \\
\hline Bank Degroof Petercam Spain & Privat Bank & 2008 \\
\hline Credit Suisse AG & Credit Suisse & 2009 \\
\hline EBN Banco de Negocios & Sociedad Española de la Banca de Negocios & 2001 \\
\hline Open Bank & Patagon Internet Bank and Patagon Bank & $\begin{array}{l}2002 \text { and } \\
2005\end{array}$ \\
\hline Renta 4 Banco & Banco Alicantino de Comercio & 2011 \\
\hline Santander Consumer Finance & HBF Banco Financiero & 2002 \\
\hline Santander Investment & $\begin{array}{l}\text { Santander Central Hispano Investment and } \\
\text { Santander Investment Services }\end{array}$ & $\begin{array}{l}2004 \text { and } \\
2006\end{array}$ \\
\hline Targobank & Banco Popular Hipotecario & 2011 \\
\hline Wizink Bank & Bancopopular-e & 2016 \\
\hline
\end{tabular}

Source: Spanish Banking Industry Statistical 2017 Yearbook. *Year the name was changed. 


\section{A.2 Descriptive statistics}

Table A4 shows the correlation matrix among all both dependent and independent variables employed in the model.

Table A4: Correlation matrix

\begin{tabular}{|c|c|c|c|c|c|c|c|c|c|c|c|c|c|c|c|}
\hline Var. & ROA & PTOI & RIMR & ESTA & EERF & SYC & $\mathrm{BS}$ & LTA & LD & DG & MP & RGDI & INF & VSPI & $\overline{\mathrm{MRO}}$ \\
\hline ROA & 1.00 & & & & & & & & & & & & & & \\
\hline PTOIR & 0.86 & 1.00 & & & & & & & & & & & & & \\
\hline IMR & 0.14 & 0.23 & 1.00 & & & & & & & & & & & & \\
\hline ESTA & 0.03 & -0.03 & -0.17 & 1.00 & & & & & & & & & & & \\
\hline EERR & 0.02 & -0.02 & -0.12 & 0.82 & 1.00 & & & & & & & & & & \\
\hline SYC & -0.04 & -0.07 & -0.03 & 0.41 & 0.50 & 1.00 & & & & & & & & & \\
\hline BS & -0.06 & -0.07 & -0.15 & 0.11 & 0.08 & 0.02 & 1.00 & & & & & & & & \\
\hline LTA & -0.02 & -0.01 & 0.33 & -0.07 & -0.09 & -0.05 & 0.30 & 1.00 & & & & & & & \\
\hline LD & 0.03 & 0.04 & 0.04 & -0.05 & -0.03 & -0.02 & -0.02 & 0.12 & 1.00 & & & & & & \\
\hline DG & -0.00 & -0.01 & -0.01 & 0.00 & -0.04 & 0.04 & -0.01 & -0.02 & -0.01 & 1.00 & & & & & \\
\hline MPI & -0.02 & -0.02 & -0.10 & 0.02 & 0.03 & -0.00 & 0.70 & 0.11 & -0.03 & 0.02 & 1.00 & & & & \\
\hline RGDP & 0.03 & 0.07 & -0.01 & -0.37 & -0.12 & -0.69 & -0.04 & -0.01 & 0.03 & -0.08 & 0.01 & 1.00 & & & \\
\hline INF & -0.05 & -0.01 & 0.11 & -0.55 & -0.63 & -0.51 & -0.06 & 0.07 & 0.04 & -0.03 & -0.00 & 0.21 & 1.00 & & \\
\hline VSPI & -0.10 & -0.09 & 0.05 & 0.20 & 0.09 & 0.62 & -0.01 & 0.00 & 0.03 & 0.07 & -0.00 & -0.64 & -0.21 & 1.00 & \\
\hline MRO & -0.02 & 0.04 & 0.15 & -0.74 & -0.81 & -0.73 & -0.07 & 0.08 & 0.07 & 0.00 & -0.00 & 0.30 & 0.76 & -0.18 & 1.00 \\
\hline
\end{tabular}

Source: Author's elaboration. Number of observations: 742. Variables $\rightarrow$ ROA: Return of assets, PTOIR: Pre-tax operating income ratio, IMR: Interest margin to total assets ratio, ESTA: Eurosystem total assets, EERR: Excess reserves, SYC: Slope of the yield curve, BS: Bank size, LTA: Loans to assets ratio, LD: Loans to deposits, DG: Deposits growth, MP: Market power index, RGDP: Real GDP growth, INF: Inflation, VSPI: Volatility of stock price index, MRO: ECB's Main refinancing operations rate.

\section{A.3 Hausman specification test}

So as to choose what model fits better with our data, I will apply the Hausman (1978) specification test. Under the null hypothesis, the Balestra-Nerlove estimator is consistent and efficient but even though the within-groups estimator is consistent, it is not efficient (Baltagi, 2008). Therefore, if I do not reject the null hypothesis, the random effects model will be chosen. On the other hand, under the alternative hypothesis, the Balestra-Nerlove estimator is inconsistent and the within-groups estimator is consistent so I will have to employ a fixed effects model. The Hausman (1978) test computes the difference between the two estimators, weighted by the inverse of the differences of the variance-covariance matrices of both estimators. It seems remarkable that the variance-covariance matrices of both estimators should be positive definite.

As the difference between the variance-covariance matrix of both estimators is not positive definite in all cases, I will base both variance-covariance matrices on disturbance variance estimate from the Balestra-Nerlove (efficient) estimator.

Table A5 shows the results of the Hausman (1978) test for the static model with all bank-specific variables and macroeconomic conditions. The fixed effect (within-groups) estimator should be used in all models.

Table A6 shows the results of the Hausman (1978) test for the dynamic model. Again, the fixed effect (within-groups) estimator should be used in all models. 
Table A5: Hausman specification test

\begin{tabular}{llllllllll}
\hline \hline & ROA & \multicolumn{3}{c}{ PTOIR } & \multicolumn{3}{c}{ IMR } \\
\hline Model & $3 \mathrm{~A}$ & $3 \mathrm{~B}$ & 3C & $6 \mathrm{~A}$ & $6 \mathrm{~B}$ & $6 \mathrm{C}$ & $9 \mathrm{~A}$ & $9 \mathrm{~B}$ & $9 \mathrm{C}$ \\
\hline$\chi^{2}(8)^{*}$ & 37.57 & 37.55 & 40.52 & 47.27 & 43.01 & 49.84 & 15.94 & 17.18 & 15.41 \\
Prob $>\chi^{2}$ & 0.00 & 0.00 & 0.00 & 0.00 & 0.00 & 0.00 & 0.04 & 0.03 & 0.05 \\
\hline \hline Soure: Author's
\end{tabular}

Source: Author's elaboration. *Degrees of freedom.

Table A6: Hausman specification test

\begin{tabular}{llllllllll}
\hline & ROA & \multicolumn{3}{c}{ PTOIR } & \multicolumn{3}{l}{ IMR } \\
\hline Model & $12 \mathrm{~A}$ & $12 \mathrm{~B}$ & $12 \mathrm{C}$ & $15 \mathrm{~A}$ & $15 \mathrm{~B}$ & $15 \mathrm{C}$ & $18 \mathrm{~A}$ & $18 \mathrm{~B}$ & $18 \mathrm{C}$ \\
\hline$\chi^{2}(9)^{*}$ & 83.88 & 83.33 & 84.15 & 96.59 & 93.82 & 97.34 & 207.38 & 202.44 & 208.95 \\
Prob $>\chi^{2}$ & 0.00 & 0.00 & 0.00 & 0.00 & 0.00 & 0.00 & 0.00 & 0.00 & 0.00 \\
\hline \hline Soure: Author's
\end{tabular}

Source: Author's elaboration. *Degrees of freedom. 


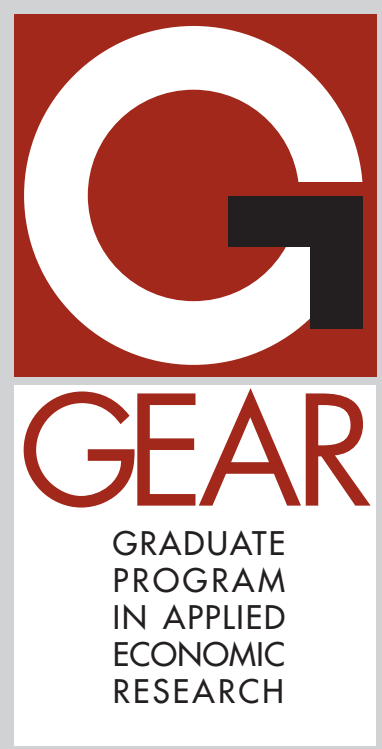

